\title{
Gemma
}

\section{PUNITIVE "JUSTICE": \\ TRACING GLOBAL (ANTI) CARCERAL DISCOURSES IN SPANISH GENDER VIOLENCE LEGISLATION AND FEMINIST MOVEMENTS}

\author{
Adrianna Rosario
}

Main Supervisor: Dr. Ana Alcázar Campos

Universidad de Granada

Support Supervisor: Dr. Berteke Waaldijk Universiteit Utrecht

Universidad de Granada Instituto Universitario de Estudios de la Mujer 


\title{
Gemma \\ European Commission ERASMUS MUNDUS
}

\section{PUNITIVE “JUSTICE”: TRACING GLOBAL (ANTI) CARCERAL DISCOURSES IN SPANISH GENDER VIOLENCE LEGISLATION AND FEMINIST MOVEMENTS}

\author{
Adrianna Rosario \\ Main Supervisor: Dr. Ana Alcázar Campos \\ Universidad de Granada \\ Support Supervisor: Dr. Berteke Waaldijk \\ Universiteit Utrecht \\ Universidad de Granada \\ Instituto Universitario de Estudios de la Mujer
}

2021

Approval signed by Main Supervisor:

Firmado por ANA ALCȦZAR

CAMPOS - 03105717G con

certificado FMT
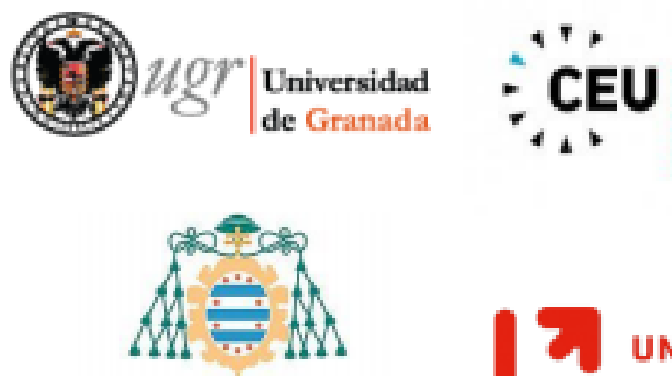

CENTRAL EUROPEAN UNIVERSITY
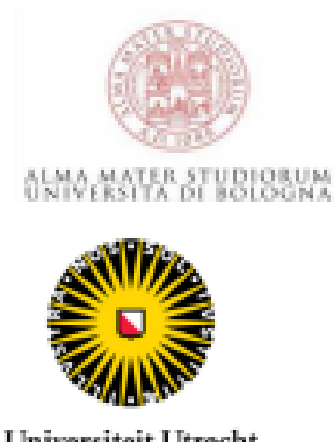


\section{Abstract}

This project traces global punitive discourses in Spanish gender violence legislation by focusing particularly on the dialectic between the law and feminist political mobilizations. It examines the rise of institutional feminism in Spain and how its embrace of neoliberal social governance culminated in very punitively focused gender violence legislation. The project compares the carceral logics and tactics embedded in the Organic Law 1/2004 for Comprehensive Measures Against Gender Violence (BOE n 313, December 29, 2004; hereafter: Law 1/2004) and the more recently proposed Organic Law for the Comprehensive Guarantee of Sexual Freedom (hereafter: The "Yes Means Yes" Law). Law 1/2004 and The Yes Means Yes Law do not illustrate all the feminist contestations around punitive tactics in the last two decades, yet they act as productive case studies given that each are cornerstone pieces of legislation that set national guidelines for preventing, accessing and intervening in gender violence and happened to dramatically expand the penal code. Using a mixed-modal methodology of legal, feminist critical discourse analysis (CDA) with a genealogical approach, this project locates the converging and diverging globalizing carceral discourses in the laws. It features anti-carceral feminist resistances, in the form of organizing artefacts, to trouble the commonsensical claim that punishment is the most "just" and effective way to resolve gender violence. Transnational feminist criminologists, queer/trans scholars, and feminists of color further contextualize how globalizing carceral logics and carceral feminisms, embedded in gendered and racialized structures of power, travel and influence legal discourses and gender violence political strategies. This project contributes to other ways of reconciling gender violence that keep survivors and their communities safer and do not perpetuate violence against queer/trans and racialized bodies.

Keywords: gender violence, (anti)-carceral feminism, abolition, neoliberalism 


\section{Resumen}

Este proyecto traza los discursos globales punitivos dentro de la legislación española sobre violencia de género, con un enfoque particular en la dialéctica entre la ley y los movimientos políticos feministas. Examina el surgimiento del feminismo institucional en España y como su adhesión a la gobernanza social neoliberal culminó en una legislación de violencia de género muy punitiva. El proyecto compara las lógicas carcelarias y tácticas incorporadas en la Ley Orgánica de Medidas de Protección Integral contra la Violencia de Género (BOE n 313, 29 de diciembre 2004; a partir de ahora: la ley 1/2004) y el Anteproyecto de Ley Orgánica de Garantía Integral de la Libertad Sexual (2020 de octubre, la ley Sí es Sí), propuesto recientemente. La ley 1/2004 y la ley Sí es Sí no se ilustran todas las contestaciones feministas sobre las tácticas punitivas en las últimas dos décadas, pero sirven como casos de estudio productivos dado que son textos legislativos que establecen guías para prevenir, acceder e intervenir en la violencia de género y también expanden el Código Penal. Usando una metodología híbrida de análisis crítico de discurso legal y feminista con una aproximación genealógica, este proyecto resalta las diferencias y similitudes entre los discursos carcelarios globalizantes en las leyes. Cuenta con las resistencias feministas anti-carcelarias en la forma de artefactos activistas para complicar el reclamo normativo que el castigo es la manera más "justa" y efectiva para resolver la violencia de género. Criminólogxs feministas transnacionales, investigadorxs queer y trans y feministas de color contextualizan como estructuras de poder racializadas y de género, viajan e influyen los discursos legales y estrategias políticas de violencia de género. Este proyecto contribuye a otras maneras de reconciliar la violencia de género que mantienen segurxs a Ixs sobrevivientes y sus comunidades sin perpetuar violencias contra cuerpxs queer, trans y racializadxs. 


\section{Acknowledgements}

bell hooks (1991) writes, "the production of feminist theory is complex, that is it is less the individual practice than we often think and usually emerges from an engagement with collective sources" (p. 3). I arrived at this thesis not on my own but thanks to many enriching conversations with my classmates, professors and colleagues. I want to thank: Ana, for her patience with my Spanish, passion for my topic and faith in my abilities; Berteke, for her calming demeanor during this stressful time and thought-provoking feedback; and my former bosses Patti and Azucena for going above and beyond to provide me with the training and experience that became indispensable to this thesis.

I am grateful for my affective support network for their support and care: my mom and dad for showing me that love and care do not know time and distances; my brothers Ryan and Ruben for being my forever role models; Jose, for holding me during the darkest moments; Molly, for always learning and growing with me; GEMMA friends for being my sounding boards; and my cat Felix who physically accompanied me more than anyone else on this journey!

Lastly, I arrived at this thesis during a physically, emotionally and politically precarious moment that influenced my writing process. I missed final moments and funerals and grieved without close loved ones. I want to acknowledge my uncle who passed from COVID-19 when I wrote this thesis. His death at the hands of a US privatized healthcare system that made him fear getting help ruthlessly underlined the way neoliberalism punishes the poor and the necessity for anti-carceral politics. 


\section{Table of Contents}

Abstract

Resumen

Acknowledgements

INTRODUCTION.

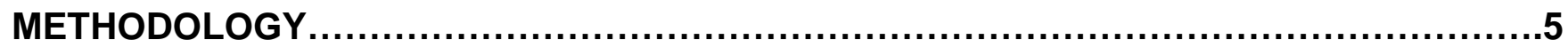

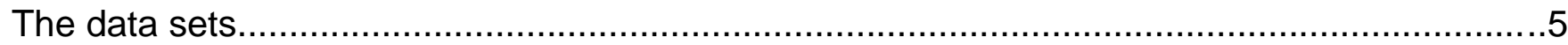

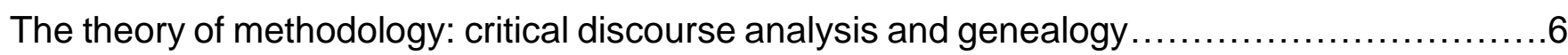

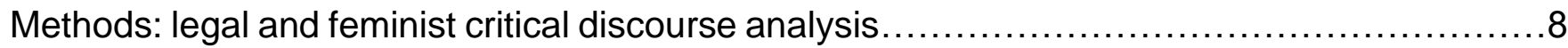

THEORETICAL PRAXIS- JOINING THEORY AND ACTIVISM: GLOBAL LANGUAGES OF

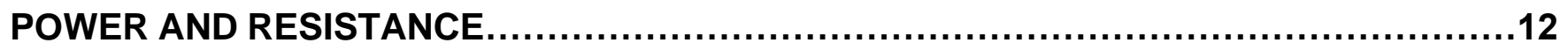

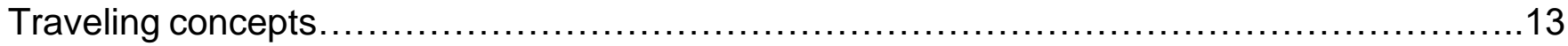

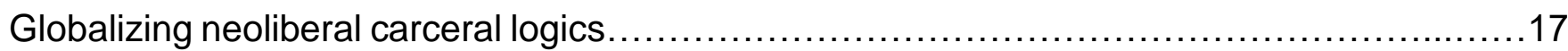

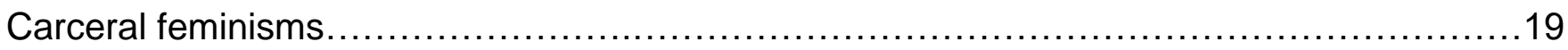

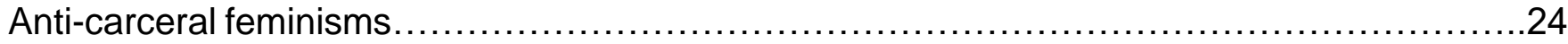

BACKGROUND- POST-FRANCO ANTI-CARCERAL SENTIMENTS IN CRESCENDO: THE RISE OF INSTITUTIONAL FEMINISM AND NEOLIBERAL GOVERNANCE...................28

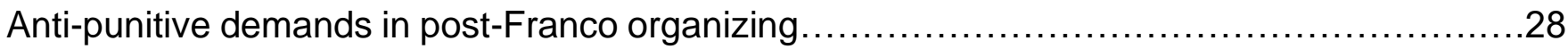

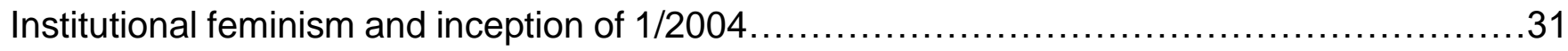

ANALYSIS- LAW 1/2004 AND THE YES MEANS YES LAW: POLICING AND PUNISHMENT

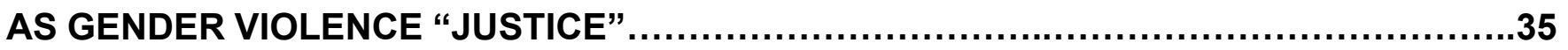

Law 1/2004: the ground-zero for gender violence punitivism .................................

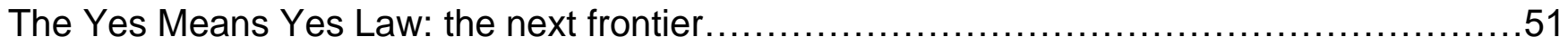

Reflections: mapping convergences and divergences....................................... 
(NOT SO) FINAL THOUGHTS

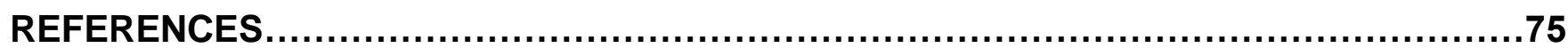




\section{INTRODUCTION}

Ruth Wilson Gilmore said, "Abolition is a theory of change, it's a theory of social life. It's about making things" (2018). Fred Moten and Stefano Harney (2013) echoed Gilmore when they wrote, "Not abolition as the elimination of anything but the founding of a new society" (p. 101). Many people mistake abolition as a reckless ideal that tears down tired social infrastructure without offering tangible alternatives to rebuilding public safety. They imagine total anarchy- a world where criminals run free, and there is no one to call when you are in trouble. Trump cultivated this imagination during the November election when many people saw nightly television advertisements of a masked robber assaulting an elderly, white woman in her own home. Black Lives Matter protesters became known as rioters who destroyed businesses and monuments, burned down police precincts and jeopardized public safety infrastructure. 1980s war on crime nostalgia ran rampant throughout the right's talking points which promised to restore law and order and protect white women from monstrous criminals who often assumed images of men of color.

Black feminist activists fired back at this assumption of police as protectors: "I think white people talked more as if the courts belonged to us and therefore should work for us, where we always saw it as belonging to someone else and talked more about how to keep it from hurting us" (Gruber, 2020, pp. 62-63). Simply calling the police for help while having a mental health crisis (Water Wallace Jr.; George Floyd), carrying a replica toy gun (Tamir Rice) or sleeping in one's own bed (Breonna Taylor) can be a death sentence. The prison abolition movement gained a lot of political traction thanks to the sweeping Black Lives Matter (BLM) protests in Summer 2020 that drew attention to historical patterns of police brutality and overreach. However, fervor for prison abolition typically comes to a screeching halt at the mention of gender violence. Even the most leftist politicians like Bernie Sanders harshly criticize the criminal justice system but do not dare to challenge gender violence bills that contribute to mass incarceration.

Aya Gruber (2020) reiterates in her book Feminist War on Crime that the task of millennial feminism lies in how to balance its disdain for both punishment and gender violence. This contradiction haunts many activists working at the intersections of racial justice and gender 
violence in the United States. As I marched masked up in the blistering heat and amidst a pandemic during a BLM protest, I pleaded with the criminal justice system for help: "Lock up the cops who killed Breonna Taylor!" Then the next minute, I rallied for its destruction: "2-4-6-8 Smash the police state!" I understood that prison abolition meant divesting from the criminal justice system in order to invest in education, health care, housing and food programs. It made sense to me that sending a few bad cops to prison would not solve policing's systemic issues nor heal communities' wounds. Yet, I harbored doubts about how we would hold "the real bad guys," such as Harvey Weinstein, accountable without a criminal justice system. In other words, I wanted to abolish prisons and lock up the cops who killed Breonna Taylor. I believed I could simultaneously toughen the criminal justice system against the "worst of the worst" and rehabilitate it for those it fails- namely, women, people of color and queer/trans people. Otherwise, how would we show people that racist, transphobic and patriarchal violence is not acceptable?

Many people suffer from a deeply ingrained punitive impulse that tells us punishment equates to accountability, safety and healing. My professional domestic violence training taught me that the police and courts failed survivors, and our goal was to make those institutions safer for them. Only a year prior to BLM summer protests, I worked in the City of Philadelphia's Office of Domestic Violence Strategies and helped coordinate trainings to better educate the police on how to best respond to domestic violence emergencies. I left every training feeling defeated as my colleagues and I tried to teach years of social work training in a two-hour annual session. I felt uneasy about the role of the police in gender violence but assumed it was an inevitable reality that just could be "tamed".

I first really engaged with anti-carceral thought through a US prison abolition lens in Summer 2020. I was drawn to the hope it instilled in me during the politically tumultuous time. I learned how women of color and trans feminists have long reimagined viable alternatives to reconciling violence that do not expand the criminal justice system and perpetuate harm. Their front-line work opened an urgent line of critique and activism that I wanted to continue connecting with in my new home in Granada, Spain. I quickly found many of the same US punitive strategies repurposed in a very distinct socio-political context in Spain. Feminists in Spain, Argentina, and 
Italy were repeating the same clear case as US prison abolitionists: locking up and isolating perpetrators, without educating them and helping them amend the harm they created, does not keep survivors or communities safer. So, if there is worldwide evidence that punitive strategies do not work and just as much evidence that investing in housing, healthcare, employment and food does, then why do some policymakers continue to pursue them?

The crux of this thesis will tackle how this contradiction continues to operate largely un-checked in mainstream feminist calls for justice transnationally and more specifically in Spain. This project will not compare US and Spanish punitive gender violence tactics but rather use my positionality as a student between US and Spanish activism and academia to highlight the globalization of carceral discourses in Spanish gender violence legislation. My contact with BLM and gender violence advocacy in a US-context initially inspired my interest in this topic. However, my reencounter with anti-carceralism in a Spanish context shifted my view to how punitive logics and resistances travel, albeit not homogeneously, across borders. My clumsy confrontations with gender violence and anti-carceral terminology insert a necessary skepticism for how I link Spanish carceral discourses to those found in the US and in other geopolitical locations.

The main goal of this project is to trace the carceral turn in mainstream gender violence demands in Spain by examining two major pieces of legislation: the Organic Law 1/2004 for Comprehensive Measures Against Gender Violence (BOE n 313, December 29, 2004; hereafter: Law 1/2004) and the proposed Organic Law for the Comprehensive Guarantee of Sexual Freedom (more colloquially known as and hereafter: The "Yes Means Yes" Law). I historically position my inquiries between the entrance of Spain into "democracy" in 1975 and present-day. I use post-Franco feminist demands as an entry-point to discuss early activist approaches to gender violence and, thereafter, trace their trajectory through the institutionalization of feminism in Spain. I answer four primary questions:

a. What role do feminist movements play in the emergence of carceral demands in Law 1/2004 and The Yes Means Yes Law?

b. What globalizing punitive discourses appear in Law 1/2004 and The Yes Means Yes Law? What counter-discourses disrupt the carceral logics embedded in each law? 
c. How do debates and contestations around Law 1/2004 and The Yes Means Yes Law spark resistance from diverse feminist groups?

d. How do the emergent carceral discourses in each respective law and resistances to those laws converge and diverge?

I frame the proliferation of punitive responses to gender violence in Spain within larger global trends toward neoliberalism (Harvey, 2007) and explain how neoliberal ideology informs carceral feminist theories and practices. Traveling concepts (Neumann \& Nünning, 2002) serve as a meta-theoretical framework to explore the problematics of translating terms gender violence and anti-carceralism from one activist or scholarly community to another. Reflecting on my confrontations within these concepts between the US and Spain offers a poignant reflection on my positionality and how to ethically draw on transnational scholars to both define and to resist globalizing carceral feminist discourses. I rely on a mixed-modal methodology of genealogy and critical discourse analysis (CDA) (Anais, 2012) to detect and counter international punitive discourses. Feminist and legal contributions to CDA (Lazar, 2007; 2018; Rajah, 2018) facilitate a critical intervention for understanding power asymmetries in legislative text. All translations of the laws and cited references are my own.

I structure these ideas in four main chapters. In the Methodology, I explain how I blend genealogy and critical discourse analysis to deconstruct the carceral logics in Law 1/2004 and The Yes Means Yes Law. In the Theoretical Praxis, I discuss the globalization of neoliberal governance in North America and Western Europe and its racializing and gendering logics. I rely on the work of anti-carceral, transnational scholars working in the fields of criminology, black and women of color feminisms, and trans/queer studies to describe and to debunk carceral feminisms. The Background outlines feminist organizing post-Franco and the events that supported the rise of institutional feminism. The Analysis names the global punitive demands that appear in Law 1/2004 and The Yes Means Yes Law by unraveling the categories of "victim" and "justice" and highlighting the resistances to those same hegemonic discourses. I wrap up the analysis by mapping the convergences and divergences between how each law incorporates global punitive discourses and how feminist groups resist. 


\section{METHODOLOGY}

The goal of this research is to examine the macro and micro dialectical relationship between national legal punitive discourses in Spain with globalizing punitive discourses and local feminist movements. I engage with a mixed-modal methodology of legal, feminist critical discourse analysis (CDA) with a genealogical approach to pinpoint how official legal discourses represent a contestation of power that constructs and is constructed by institutional feminisms and alternative anti-carceral feminisms. I blend feminist, legal CDA and genealogical approaches because they are both similar post-structuralist, qualitative methodologies that unravel structures of power and center resistances. Although traveling concepts serve as a meta-methodological approach in the Theoretical Praxis, I separate it into the following chapter to avoid confusion that this work is comparative. Traveling concepts directed the choices I made about language and scholars, but it was not a vector of CDA-genealogical analysis that I employed to read against the two laws.

\section{The data sets}

I select two pieces of legislation to analyze carceral discourses: the Organic Law Comprehensive Measures Against Gender Violence (2004) and the proposed Organic Law for the Comprehensive Guarantee of Sexual Freedom (October 2021). I limit my source material in order to provide depth and clarity to my analyses while keeping my project manageable for a master's level thesis. Law 1/2004 and The Yes Means Yes Law are productive case studies for analyzing national courses because they dictate how all health, educational, workplace and penal institutions must prevent, identify and intervene in gender violence. As comprehensive laws, they have the power to coordinate the intervention and prevention strategies of various bureaucratic institutions, to designate long-term budget obligations and to modify many judicial codes at once. ${ }^{1}$ The two selected laws do not encapsulate all gender violence carceral discourses and their respective feminist resistances in the last two decades, but each are

\footnotetext{
${ }^{1}$ While autonomous communities must abide by national laws and civil and criminal codes, they also have the power to expand gender violence provision and their local jurisprudence may affect how Law 1/2004 is integrated, applied or expanded within autonomous communities.
} 
important pieces of legislation that establish large-scale rules and procedures and trigger nationwide reactions.

The data set for counter discourses is considerably larger and more fluid. I present anti-carceral discourses through the works of transnational activists and scholars that I elaborate on in the Theoretical Praxis and apply in the Analysis. Specifically in response to Law 1/2004 and The Yes Means Yes Law, I examine several actions, materials, statements and publications by local and national activists and organizations. I originally planned to interview activists and professionals working within collectives, organizations and governmental entities to gather counter-discourses. However, the pandemic restrictions posed several logistical obstacles to networking with individuals. Though less personal and affective, the written discourses still serve to interrupt hegemonic ideal victim and punishment narratives in Law 1/2004 and The Yes Means Yes Law.

In the Analysis chapter, I analyze the data set by interrogating the legal categories: "victim" and "justice." After locating the categories in the text, I interrogate the underlying ideologies and assumptions that inform their semantic context beyond their face-level usage in the law. I undertake a genealogical critical discourse analysis (Anais, 2013) while using the specific methods proposed by feminist (Lazar, 2007; 2018) and legal (Rajah, 2018) approaches to CDA (Fairclough 1989; 1995). The overarching goal of the analysis is to link the semiotic and material operations of the categories to larger trends in global punitive discourses. Between the two laws, I intend to map convergences and divergences in carceral rhetoric and tactics as well as their accompanying resistances.

\section{The theory of methodology: genealogical critical discourse analysis}

Prior to elaborating on the specific methods applied to analyze the laws, I first elaborate on the theory that informs my methodology. In this section, I explore the meaning of discourse, how discourse emerges and how to assemble the discursive archive. I interpret these questions through the lens of a blended genealogical critical discourse analysis proposed by Anais (2013). 
Genealogy and CDA are a productive duo because they share the same core philosophies while complementing one another's gaps.

To begin, genealogy and CDA agree on the definition and formation of discourse. Both approaches understand discourse as oral and textual "communicative events" that signal "what can be said, by whom and in what fashion" (Anais, 2013, p. 129). They search for, not for the ultimate truth, but the "symbolic meanings associated with oft-repeated words and phrases, and with recurrent frames, narratives, and cultural scripts" (p. 129). In addition, CDA and genealogy view discourse and the social as dialectical, wherein discourse constitutes and is constituted by social practices. Co-constitution implies that "every act of meaning-making through spoken and written language use and other forms of semiosis contributes to the reproduction and maintenance of the social order, and also in the sense of resisting and transforming that order" (Lazar, 2007, p. 11). Discourse then builds on post-structuralists theories that emphasize norms as a site of struggle and contestation (Lazar, 2007, p. 4).

Genealogy improves CDA's ahistorical approach to the assemblage of the archive. The discourse analyst typically uses several key documents to tell a story with a beginning, middle and end. The genealogist, on the other hand, rejects mapping the "whole story" of a particular set of practices through source materials and searches for meaning through the relationality of parallel discourses (Anais, 2013, p. 130). Genealogists focus on the ruptures and convergences among texts, paying attention to patterns of contestation that make certain discourse visible or marginal (p. 133). To this end, genealogy requires a vast archive of source materials to illuminate the complex portrait of contested social practices that are neither static nor a totalizing reality (p.130). Despite its strong epistemological and theoretical foundation, experts criticize genealogy for its ambiguity with how to handle and process source materials (p. 129). CDA makes genealogy more manageable by placing more limitations on the number of texts studied and offering clearer analytical conventions.

Bridging CDA and genealogy together can attend to the ahistoricism found in CDA while providing a more manageable approach to collecting data and curating a research design (Anais, 2013, p. 131). A genealogical CDA avoids CDA's traditional tendency to tell the whole story of a 
particular practice or institution but instead provides a relational snapshot through the examination of several noteworthy texts. CDA infuses Foucauldian thought with a practical and systematic guide for executing its central goal to counter hegemonic narratives. Together genealogical CDA accomplishes their goals of disturbing historical memory and demonstrating how, and through what means of power, certain discourses remain dominant (p. 133).

\section{Methods: legal and feminist critical discourse analysis}

In the last section, I argue that CDA lends a clearer guide of how to analyze a given discursive archive. Here, I will discuss the methods that I use to untangle the hegemonic discourses found in Law 1/2004 and The Yes Means Yes Law. I first introduce overarching CDA methods, proposed by Fairclough (1989; 1995), and the selected CDA convention of reading along and against text that will guide my analysis. Next, I delve into the specific perspectives brought forth from the legal field and feminist studies that support the critical aspect of discourse analysis.

Fairclough provides a broad model for how I frame my research object (the laws) and conduct their analysis. According to Fairclough (1989; 1995) discourse analysis involves three respective interrelated processes of dimensions and analysis of discourse. The dimensions of discourse include: the object of analysis, its production and reception, and its socio-historical conditions. The processes of analysis include text analysis (description), processing analysis (interpretation) and social analysis (explanation). Fairclough (1989; 1995) emphasizes that the order of analysis is not important but rather the presence and interconnection between the three which will reveal the relevant patterns and disjunctions that need to be described, interpreted and explained. Fairclough delineates the scope of a given research object and the major elements of discourse analysis. Next, I turn to Anais (2013) who renders a step-by-step approach to eliciting a description, interpretation and explanation from a text.

Anais (2013) suggests the CDA approach of reading along and against text as a practical method befitting to genealogy. Reading along the text involves "taking the meanings created in the text at face value, paying attention to how the text is organized and to how language is deployed therein" (Anais, 2013, p. 133). In other words, I examine the content of text and decipher its 
meaning, attuning to how it justifies certain claims. I connect the claims and reasonings to larger socio-political conditions and trends presented in the Theoretical Praxis. Reading along text also requires paying close attention to the materiality of the text "acquainting myself with the construction of official documentary systems" (p. 133). Legal CDA provides more specific guidance on how to situate legal texts according to layout and format.

Reading against the text is the second step in the process and moves beyond the descriptive and interpretative to the (critical) explanatory. Reading against the text requires: "looking for silences, questioning the serialization of events, considering accounts which might run counter to the official position portrayed in the text and deliberating on what accounts might be countered by a proactive rhetoric" (Anais, 2007, p. 133). When reading against the text, I pinpoint the "problems" of such discursive framings relying on counter-discourses, also presented in the Theoretical Praxis, to explain its ill consequences. By centering alternative discourses, I can problematize hegemonic categories and outline through which means of power their embedded meanings take hold (Anais, 2007, p. 133). Beyond academic theories, I center invisibilized discourses through material resistances (activist publications, statements, protests and actions). Foucault (1980) insisted that searching for voices in text, either omitted or distorted, is critical for a genealogical analysis. To this end, reading against text does not intend to "liberate" the marginalized nor diagnose reasons for their subjugation, but it is still politically motivated as it seeks to trouble categorizations and to consider alternative ways of being (Anais, 2007, p. 133). Finally, I transition to legal and feminist CDA which infuse the process of reading along and against text with important interventions for reaching a feminist analysis of legislative text.

Legal CDA articulates how to read along and against text through analysis of its legal categories. It recommends deconstructing legal categories to untangle the claims and reasonings behind legal discourse. Rajah (2018) writes, "when law is approached as 'acts of language [that] are actions in the world' (White 1990, ix), legal categories become central to the manner in which law functions as a scheme of interpretation (Kelsen, 1967, p. 4)" (p. 485). Identifying and unpacking the legal categories "victim" and "justice" can yield critical insights into the concealed debates and contestations that generate terminological constructions. From this view, these 
gender violence legal categories are not one-dimensional but a result of complex struggles for power on local, national and transnational levels (p. 485).

Feminist CDA offers several methodological interventions, including analytical activism and selfreflexivity, for reading against text. Analytical activism encourages researchers to understand gender as a diverse, flux and plural category in which individuals negotiate multiple oppressions (Lazar, 2018, pp. 372-373). Because patriarchy intersects with cis-heteronormativity, colonialism, capitalism and neoliberalism, gender is neither a universal material nor discursive experience (Lazar, 2018, p. 373). Analytical activism is essential for treating not only identities but also the legal categories of analysis as interpretative and culturally situated categories. Analytical activism claims textual deconstruction is an act of activism because it can create critical awareness and effect social transformation (Lazar, 2007, p. 6). Visibilizing marginalized feminisms and linking research to a specific political goal is distinct in comparison to the larger male-dominated, positivist CDA field. Analytical activism, as a method, situates my analysis between theory and praxis and connects my work to local and global movements who seek to resist carceral strategies and to reimagine transformative solutions.

Self-reflexivity is another ongoing methodological practice that I attempt to extend throughout this entire thesis from how I design my research question to how I support my arguments and present my research. According to Lazar (2018), scholars, while motivated by social justice, may inadvertently "reconstitute patterns of privilege and exclusion or bar progressive social change" (p. 374). As a person from the United States working in Spain, I am conscious of the sensibilities around researching a community that is not (intimately) my own. I navigate this position by working under the direction of my supervisor and doctoral mentor who are local Spanish scholars and keep my work close to the specific socio-political terrain and local authors and activisms. I make careful decisions and give explanations for how I support my critiques using transnational concepts and theories especially in the Theoretical Praxis and Analysis.

Additionally, self-reflexivity requires explicitly naming my political goals and role in movements while presenting my research. Even though I am "new" to this work, anti-carceral feminism is not. Emily Thuma (2019) describes how much of early US anti-carceral feminism grew from 
incarcerated women of color organizing from within jails and collaborating with women of color activists on the outside- many of whom the government directly targeted and jailed for leftist "terrorist" activity. bell hooks (1991) warns against repeating the trend of white women in hierarchal academic positions who rely on the works of less visible feminist scholars without giving recognition to these sources (p. 3). I have the privilege of picking up activism, from women of color, as a privileged white scholar with government funding and access to safety. This project does not create something new but builds on and works in conjunction with anti-carceral movements in Spain and the US.

To conclude, Fairclough's (1989; 1995) three-dimensional CDA analysis is the overarching methodological blueprint for analyzing the carceral discourses in Law 1/2004 and Yes Means Yes. Reading along and against text consists of identifying the categories of analysis, deciphering their embedded carceral discourses and offering alternative visions of resolving gender violence. I read against the text by using the method suggestions from legal (Rajah 2018) and feminist CDA (Lazar, 2007; 2018) including categorical analysis, analytical activism and selfreflexivity. Analytical activism explicitly links deconstructive analysis to practical political goalsa theme I explore more in the following section that weaves theory and activism. 


\section{THEORETICAL PRAXIS- JOINING THEORY AND ACTIVISM: GLOBAL LANGUAGES OF POWER AND RESISTANCE}

"I found a place of sanctuary in 'theorizing', in making sense out of what was happening. I found a place where I could imagine possible futures, a place where life could be lived differently" (hooks, 1991, p. 2).

bell hooks writes that when we base theory on our lived experience, healing and collective liberation, there is not any gap between theory and practice (p. 2). She explains that theory nor feminism is inherently revolutionary, but we move closer to feminist transformation when we root it in our concrete desires "to make sense of everyday life experience" and "critically intervene in [our] lives and the lives of others" (p. 8). I introduced this project from my personal uneasiness with abolition, and I again begin this chapter with my uncomfortable encounters with language. I engage with traveling concepts to practice self-reflexivity, both entangling myself with theory and grounding my work in political commitments. I frame the rest of the chapter according to a similar ideal. I blur the lines between theory and activism because anti-carceral theory grew out of concrete organizing against the post-slavery, racist state violence in the US and post-Franco fascist repression in Spain. I keep the US context close in this chapter, not to compare nor merge US and Spanish carceral geographies, but demonstrate, through my own personal border crossing, how carceral discourses and anti-carceral feminisms are globalizing symptoms and reactions to (distinct) oppressive histories and the rise of neoliberalism.

I split the chapter between theories and practices, illustrating how both interact in a "reciprocal process where one enables the other" (hooks, 1991, p. 2). I explain how neoliberalism, as a global-capitalist political project, has introduced similar racializing and gendering logics of narrowly conceptualizing and punitively responding to social inequalities since the 1970s. I draw on scholars who discuss the characteristics and effects of carceral feminist constructions of victimhood and justice and underline their curious alliance with right-wing crime-control policies. I then examine non-punitive gender violence proposals that remain on the margins but offer a hopeful, rehabilitative and distributional path forward. My goal of this chapter is to disentangle 
rhetoric that prison abolition is dangerous or a lofty ideal and exemplify how anti-carceral theory has always been tied to life-saving praxis.

\section{Traveling concepts}

Birgit Neumann and Ansgar Nünning (2002) describe traveling concepts as a "meta-theoretical framework for developing a self-reflexive approach to the study of culture" (p. 3). As a cultural heuristic, traveling concepts draw attention to the "epistemological, cultural and political implications of the theories and concepts we endorse" (p. 3). Research focused on culture within a globalizing world, often conducted by privileged researchers in the US, too often wholesale applies concepts without considering how their meanings and operational values shift between academic disciplines, socio-political contexts and historical time periods (p. 3). Neumann and Nünning recommend travelling elsewhere as a method for placing different approaches to concepts against one another to lay bare "selective appropriations, productive misunderstandings and discontinuous translations according to historical and local circumstances" (p. 5). Traveling elsewhere requires explicitly naming differences, tensions and antagonisms to bring together transnational cultural phenomena under the umbrella of a singular concept (p. 7).

I use traveling elsewhere as a micro-methodology for questioning and justifying the language I use and sources I reference. I start with examining my "contact zones" with anti-carceralism and gender violence- two terms that frame this project and that I do not want to take for granted. My everyday experiences meeting, clashing and grappling with these concepts between the US and Spain speak to not only the dilemmas but the advantages of connecting transnational theories and practices. Cautiously bringing concepts together highlights how carceral logics globalize and resistances emerge from similar (but not identical) motivations to topple oppressive systems. Learning from and re-purposing one another's terminology and knowledges presents an opportunity to link movements, attend to analytical gaps and generate more creative solutions to resolve gender violence. 
Anti-carceralism, anti-punitivism or gender violence: In the US, I am comfortable evoking the term abolition and trusting that those around me understand I am referring to abolishing prisons and police. Yet beyond the US, abolition is often a prickly term because it is an "irrelevant" political goal, or it can signify allegiance to radical feminist and conservative religious abolitionists. This became glaringly clear when I initially framed my project around abolition which often triggered discomfort and confusion in Spain because: one, racist policing and mass incarceration is overwhelmingly viewed as a "US problem" and, two, abolition is exclusively associated with criminalizing sex work. It frustrated me that the former comment elides Spain's own histories of colonialism and contemporary anti-migrant projects. While it is true the US holds the highest world incarceration rate and quintuples that of Spain, Spain's rate still beats out the rest of Western Europe (World Population Review, 2021). The United Nations has also accused Spain of more human rights violations against people of afro-descent than any other nation apart from the US (Rights International Spain, 2020).

Perhaps another important element is the Spanish left's relationship with the law. Many feminist reformists were skeptical of the criminal justice system, but they prioritized the law as a vehicle for social change- an ethic that has persisted today thanks to the securing of institutional feminists to power. Even the most prominent Spanish academic critics of criminalization (Larrauri, Laurenzo-Copello, Maqueda-Abreu, Juliano, Bodelón González) do not call for total abolition of the criminal justice system, as sometimes seen in the US, but a severe divestment from its role in social policy. The law is viewed as patriarchal but not an appendage of white supremacy and slavery as in the US- the latter framing which engenders abolishment rather than divestment.

Moving forward, I locate my project in anti-carceral and anti-punitive, rather than abolitionist, discourses in Spain to be careful about my political motivations and how I traverse conflicting language. I use anti-carceralism and anti-punitivism to maintain geographical and political specificity and distance myself from anti-sex work abolitionism. At times, I utilize the term abolition to reference prison abolition feminisms that offer important insights from anti-racist feminists on how prisons and policing function as historic racializing and colonial technologiesan analysis that is largely missing from Spanish feminist critiques of criminalization. I propose 
anti-carceralism as a political commitment to dismantling carceral responses to social issues and that treats criminalization as a tool for enforcing the gender binary and whiteness.

Gender violence, domestic violence, or violence against women: The United Nations first institutionalized the term violence against women and girls at 1993 World Conference on Human Rights. At first glance, the wide international recognition of violence against women and girls may insinuate a certain stability and agreement of meaning. Yet scholars, activists and institutions have long contested the terminologies violence against women, gender violence and domestic violence on world, national and local stages. Gender violence does not assume the same meaning nor receive the same response across its border "trips".

In my previous job working at a local domestic violence governmental office in Philadelphia, I witnessed many activists reject the term gender violence because it is often default for violence against cis women and "does not create a welcoming space" for male, queer and trans survivors. I distinctly remember using the term gender violence in a meeting with another non-profit professional when she quickly responded, "Are we still using that term? Don't we all agree that violence happens to all genders?" I did not necessarily disagree, but there was a certain neoliberal-ness to how gender-neutral language, in this case, was employed to obscure how different gendered, racialized and other intersecting identities shape one's proximity to violence.

In other places like Spain, feminists have widely rejected the term domestic violence since the 1990s. Feminists in Spain tend to argue that domestic violence does not recognize the inequality between men and women that drives gender-specific violence nor the violence that occurs outside of the nuclear family home (Larrauri, 2007, p. 92). For that reason, feminists largely opt for the term gender violence to highlight the structural inequalities between men and women. Still, some Spanish feminists have critiqued gender violence for invisibilizing how victims are disproportionately women (p. 47). Mainstream feminists recognize that this diagnosis enforces a binary victim-victimizer equation, which excludes queer relationships and trans identities. However, (cis) women specific language is often treated as unfortunate but "acceptable" collateral damage given the absolute necessity to underline violence against women exercised by men (p. 92). 
Between these two examples in the U.S. and Spain, there are two zero-sum language arguments. On one side, there is gender-neutral language, while in the spirit of inclusivity, flattens inequalities around who is more likely to experience violence. On the other side, is ciswoman-specific language that recognizes gender inequality in a narrow, cisheternormative vacuum. Both narratives blur how gendered structures of power, derived from enforcing and transgressing gender norms and the gender binary, and other intersecting identities such as race, immigration status, ability, and class, inform higher rates of violence. My conversations traveling from terminologies and discontentment with their scopes made me ruminate about what term I would center in this project and how I would define it.

In the end, I settle on gender violence as encompassing the violence, harassment, discrimination, or bullying driven by gender inequality and the norm-enforcing gender binary. I utilize gender-neutral pronouns but do not keep my approach to violence "gender-numb" given that queer and trans deviation from the social expectations of the gender binary ${ }^{2}$ produce structural traumas that lay the conditions for abuse. Many queer people face more adverse health, employment, poverty, and homelessness outcomes due to social exclusion. These oppressions carry unique traumas that make queer people more vulnerable to abuse (Waters et al., 2015). Queer and trans people disproportionally suffer from intimate partner violence, sexual violence and murder. ${ }^{3}$ Additionally, I do not treat gender as the sole cause of gender violence given that plural identities shape one's specific experience with violence. Finally, I view gender violence in a dialectical relationship with the individual and structural where governmental policy and societal norms interact to position racialized and trans people's vulnerability to harm and overall life chances.

\footnotetext{
${ }^{2}$ Marquis Bey (2021) discusses how deviating from gender norms may trigger violence beyond gender and sexuality labels. They argue that gender nonconformity makes otherwise "privatized sexualities" (lesbian, bisexual, gay) visible as violating gender norms. Therefore, LGBT as a descriptor violence upholds singularized identity politics that prevents one from understanding the leakiness of gender and sexuality and the full scope of gendered violence (p. 192).

${ }^{3}$ Data shows that intimate partner violence in lesbian and gay couples is comparable to (Turrell, 2000) or higher than that among heterosexual couples (Messinger, 2011; Kelley et.al., 2012). The few statistics available about trans violence indicate that trans-murder is a global health crisis. According to a data gathered by Transrespect Versus Transphobia Worldwide (TvT), a research entity of Transgender Europe, more than 350 transgender and gender non-conforming people were murdered between the beginning of October 2019 and the end of September 2020 (Clifton, 2021).
} 
With these reflections, I explore how anti-carceralism and gender violence are flux categories that vary in meaning from place to place. I make careful decisions about what terminology I use while studying Spanish punitive discourses and interconnecting them to global trends. This is especially relevant in the following sections where I shift between US and Spanish theories and practices and in the Analysis where I critique legal categories utilizing transnational voices.

\section{Globalizing neoliberal carceral logics}

Neoliberalism has been the primary global driver of the expansion and hardening of punitive social policies in the US, Western Europe and Latin America. Loïc Wacquant (2009) locates the rise of neoliberalism in the US to the mid-1970s and its spread to Western Europe to the early 2000s (p. 3). He argues that the US has been the "theoretical and practical motor for the elaboration and planetary dissemination" of neoliberalism as a political project (p. 20). Wacquant argues that it is fruitful to trace the emergence of neoliberalism in the US to "discover the possible, nay probable, contours of the future landscape of police, justice and prisons in European and Latin American countries" (p. 20). His positioning of the US as a global exporter of neoliberal "theories, slogans and measures" further endorses the way I use the US as an entry point and shift between US and Spanish theories and practices in this chapter.

Wacquant's astute observations on the contextual differences between how neoliberalism diffuses into US and Western European countries further undergirds the necessity for attending to "specific national history, social configurations and political traditions" (p. 23). He notes how the deep roots of the social welfare state, the lack of persuasive influence of individualism, and the absence of severe ethno-racial divides make it less likely that Europe will rapidly adopt punitive strategies (p. 23). Of course, Wacquant hypothesized this before the increase in migration to the European continent from Northern and Sub-Saharan Africa and the rise of rightwing electoral prominence. In any case, his theorizations that neoliberal logics and tactics learn from one another, even if not homogeneously, establish a critical framework for how I approach globalizing neoliberal logics. 
What comprises the neoliberal political project that surmounted political divides between the left and right and enraptured much of the world between the mid-1970s and early 2000s? David Harvey (2007) discusses how neoliberalism's central claim is that the capitalist free market is a legitimate ethic for governing both economic and social issues. Neoliberalism posits that the world is post-equality and identity-based politics will only divide populations, hence it relies on color-blind arguments that flatten inequalities and endorse individualist discourses. Neoliberalism manifests differently according to specific state structures and histories, but it often shares several key features: it thrives against the backdrop of job precarity and mass unemployment; it strives to unravel social welfare structures; and it works to harden the punitive system (Wacquant, 2009, p. 3). This self-perpetuating triad driving neoliberal governance privatizes social welfare and liberates itself from the responsibility to care for the needs of the population. It replaces rehabilitative social policy with a "managerialist approach centered on cost-driven administration of carceral stocks and flows" that provide the foundation for the privatization of "correctional services" (Wacquant, 2009, pp. 2-3). It also suggests that all individuals can access well-being and prosperity if they work hard enough. This political shift displaces social welfare into the private sphere and compartmentalizes social issues. It forces social justice movements to "professionalize" in order to survive and upends intersectional grassroots and direct-action projects (Stanley \& Smith, 2011, p. 25).

Neoliberalism embraces a distinctly punitive logic that supposes it can attend to the "errors" of the free market through law and punishment. It individualizes social ills to the moral character of a few bad actors, rather than the effects of social inequalities. Such narratives are tailor-made to villainize "the (dark-skinned) figure of the street delinquent, the 'welfare queens', the homeless, the unemployed, the drug addicts, the street sex workers and (postcolonial) immigrants" (Wacquant, 2009, p. 2). Marginalized populations become "natural vectors of a pandemic of minor offenses that poison daily life and the progenitors of 'urban violence' bordering on collective chaos" (Wacquant, 2009, p. 2). Dolores Juliano (2020) notes how policing symptoms rather than attending to the roots of social inequalities does not decrease crime. In fact, policing only aggravates the very state of emergency that it claims to ameliorate (p. 1). Neoliberal politicians often rely on a state of emergency to cultivate a sense of moral panic that evades the need for evidence and caters to short-term "whatever means necessary policy" 
(Ávila-Cantos \& García-García, 2013, p. 78). Wacquant (2009) suggests that the "blurring of crime, poverty and immigration in the media as well by the constant confusion of insecurity and the "feeling of insecurity" have led to unprecedented political consensus and public support across class lines (p. 3). Emergencies prey on bigoted fears by constructing criminals as monstrous and evil making crime seem inevitable to human nature rather than orchestrated and dependent on government policy (Ávila-Cantos \& García-García, 2013, p. 73). By reducing violence and suffering to the fault of a few bad actors, neoliberal governments avoid responding to questions about its own role in perpetrating structural violence. As such, neoliberalism rejects structural influences on behavior, opting for individual culpability rather than collective culpability, and insists that the state can extract "bad individuals" from society like a cancer (Gruber, 2020, p. 66).

The proliferation of punitive responses to social issues reaches beyond the singular institution of prison. As Foucault (1975) theorizes, prisons are just one aspect of a vast network of carceral technologies, including schools, hospitals, military institutions and factories, that discipline the body. Neoliberal carceralism most explicitly reveals itself in the form of harsher sentences, expedition of carceral procedures and expansion of judicial powers. Yet in an even more troubling and pernicious arena, punitivism creeps into the cracks of social "welfare" systems through policies that monitor and punish the poor who interface with child welfare services, schools, hospitals, and borders- forming what Ruth Wilson Gilmore calls "carceral geography" (Kushner, 2019). Carceral geography "examines the complex interrelationships among landscape, natural resources, political economy, infrastructure and the policing, jailing, caging and controlling of populations" (Kushner, 2019). Carceral geographies map the failure of punishment to resolve problems related to the environment, child welfare, native lands, immigration, economic equity and gender violence (Kushner, 2019). In the following sections, I specifically discuss the punitive footprint of neoliberalism in the mainstream framings of and interventions into gender violence.

\section{Carceral feminisms}


Symbolic rhetoric: In 2007, feminist sociologist, Elizabeth Bernstein coined carceral feminism to explain the growing belief that toughening prison sentences and criminal justice procedures improves gender equality outcomes. In the early 2000s, scholars in Spain began to note the punitive turn in social interventions (Ávila-Cantos \& Malo de Molina-Bodelón, 2010; GarcíaGarcía, 2013). Around the same time, scholars from the US (Bumiller, 2008; Coker, 2001; Gottschalk, 2006; Halley, 2008) began to theorize about carceral feminism. However, US and Spanish scholars responded to distinct socio-historical contexts: one, the US adopted neoliberalism a quarter-century sooner and, two, the early faces of carceral activism were different. In the US, the trailblazers of carceral feminism were primarily white legal and prosecutor feminists who first started advocating for harsher penalties and more police involvement in the early 1960s and late 1970s (Gruber, 2020, p. 45). In Spain, the solidification of carceral demands in the mainstream feminist agenda grew from the rise of institutional feminism and neoliberal governance in the 1990s (Uría-Ríos, 2009, p. 122). In any case, both movements shifted from margins to the center thanks to the ability of "war on gender violence crime" to unite both leftist and right-wing parties. In the following chapter, I will cover more of the historical emergence of carceral feminism in Spain. Whereas, in this section, I will further describe the broad characteristics of carceral feminisms and their respective implications.

Carceral feminism, derived from neoliberal carceral logics, relies on a narrow version of victimhood and justice that panders to racist and patriarchal norms. In crime-control discourse, the ideal victim is an innocent, hysterical and brutalized middle-class, cis-white woman who desires swift paternal rescue by the state and punishment of the monstrous offender (Gruber, 2020 , p. 96). The "monstrous" perpetrator often assumes images of men of color and immigrant men in poorer countries who are supposedly more violent and sexist towards women than white men. The idea of protecting women, especially women of color from men of color, has been used historically to justify U.S. and European carceral and colonial projects (Spade, 2013, p. 1038).

Sara Farris (2017) describes how since the arrival of greater numbers of migrants from the Middle East to the US and Europe right-wing nationalists and neoliberal feminist groups have joined forces to advocate for anti-immigration policy in the name of "women's rights". These 
discourses often involve saving passive and oppressed Muslim women from "backwards" and "perverted" Muslim men. Farris proposes the term "femonationalism" to describe this contemporary wave of nationalist, xenophobic and paternalistic rhetoric that supposes criminalizing migration will resolve gender violence. Femonationalism represents a distinct brand of carceral feminism used to stigmatize Islamic populations in the US and Europe. Saez Valcarcel (2007) expands on this idea by arguing that criminalizing immigrant men allows white people from the Global North to feel more civilized than the poor people from "undeveloped cultures" who are more "chauvinist, violent and brutish," all while masking the unequal economic and social conditions that inform behaviors that provoke more violence in marginalized communities (as cited in Laurenzo-Copello, Maqueda-Abreu \& Rubio-Castro, 2008, pp. 354355).

Carceral feminism often utilizes "every woman" narratives that proclaim violence happens to all women equally, and hence, ignores evidence that indicates privilege shapes one's proximity to violence. Kimberle Crenshaw (1989) warned three decades ago that essentialized depictions of identity only visibilize the most powerful within that respective group. In the case of gender violence, "every woman" narratives center a white, middle class cis-woman experience. This gendered and racialized portrait of victimhood makes people of color and trans people nonlegible as survivors of gender violence. Essentializing victims according to a limited definition of womanhood invisibilizes lifelong structural and intersectional violences experienced by people who deviate from assigned gender norms and cannot access whiteness.

Material practices: Carceral feminists bolster their visions of victimhood and justice through several practices. First, carceral feminists advocate for prosecution rules that restrict the agency of survivors and, sometimes even, criminalize them for non-compliance. In both the US and Spain, carceral feminists have secured many of the same legal changes that restrict a survivor's agency and increase their own ability to be criminalized. For example, laws such as mandatory arrest, automatic no contact order, no-drop prosecution, convictions with/out victim participation, deny survivors from independently filing or dropping charges or contacting the offender. In Spain, a survivor may even face legal penalty for dropping charges for "lack of cooperation" or "falsified testimony" (Laurenzo-Copello, Maqueda-Abreu \& Rubio-Castro, 2008, p. 342). The authors note 
how this paternalistic and rigid attitude, that reduces women's legal rights to those of minors or incapacitated, does not align with feminist discourse that demands equality (p. 243). Laws that do not let survivors make decisions for themselves and insist on the need for "state protection" reinforce a victimization narrative characterized by helplessness and passivity (p. 397). As such, these laws act as mechanisms of social control that reproduce gender norms and stereotypes, rather than a means of empowerment and self-realization (p. 376).

Second, carceral feminists urge for harsher sentences. In both Spain and the US sentences for gender violence crimes, across the board, have steadily increased (Larrauri, 2007, p. 60 \& Gruber, 2020, p. 44). In some states in the US and the United Kingdom, carceral feminists have also established mandatory minimum sentences that shift non-consensual, non-forcible behaviors from serious misdemeanors to high-degree felonies worthy of substantial jail time (Gruber, 2020, p. 196). This curiously mandates the same sentence for non-consensual experiences, from condom removal during sex to gang rape, equating their gravity and obscuring the complexities of sex and consent. Carceral feminists often justify higher sentences by arguing that higher penalties will teach men that they cannot get away with abuse and violation. Despite widespread feminists' claims that all male perpetrators do not pay for their crimes, there is not any evidence that suggests that black men in the U.S. (Gruber, 2020, p.166) nor immigrant men in Spain have the same privilege (Laurenzo-Copello, Maqueda-Abreu \& Rubio-Castro, 2008, p. 355). Even though there is an ingrained impulse to punish the worst of the worst, reactive penal policy will always fall most harshly and widely on poor people of color because the penal system is beholden to larger social biases. White and privileged men have the power to evade tougher sentencing laws "placing the burden of increased criminalization on the poor minorities who form the policed segment of the population" (Laurenzo-Copello, Maqueda-Abreu \& Rubio-Castro, 2008, p. 207).

Next, carceral feminists aim to strengthen their relationship with police and courts by integrating their responses. This typically looks like policies that require survivors to interface with the criminal justice system in order to gain access to state resources, such as paid time off, medical compensation, and temporary and long-term housing. For example, the Andalusian regional government in Spain passed a law in 2009 which mandated that intimate partner violence 
survivors must file a criminal complaint in order to enter a long-term shelter. In other words, survivors must register with the criminal justice system in order to receive recognition and support from the state (Valenzuela-Vela \& Alcázar-Campos, 2019, p. 7). The integration of the criminal justice system and social services pose many obstacles to queer/trans, people of color, migrants and the poor who may be reluctant to involve the police in fear of retaliation from their partner of communities, police violence or overlook, child custody battles or deportation. These obstacles discourage marginalized people, who often face disproportionately cruel punishment, from seeking resources and finding safety from violence. Studies (Sherman et.al., 1992; McCloskey \& Sitaker, 2009) also show that police more often identify gender nonconforming people and black women as primary aggressors rather than victims (as cited in Gruber, 2020, p. 87-89).

Finally, carceral feminisms collaborate with police to share and blend tactics. Ávila-Cantos and García-García (2013) note how police in Spain have embraced activist language common in social interventions such as "multidisciplinary response, empathy, companionship" and tactics such as resource brochures, meetings with schools and associations and talks in community centers (p. 63). This smoke and mirrors tactic assumes that police aim to support and to rehabilitate people in the community. However, neoliberal police ethics practice criminalization rather than rehabilitation to minimize the threat of violence. Social workers in Spain have dually embraced policing tactics. The authors signal how social workers, who are more present in poor and racially segregated areas, often act as surveillance agents detecting "risk" of those who may potentially disrupt the "productivity" of the population (p. 66). Social workers systematically document whether a child is more likely to commit a crime based on certain demographic characteristics and observed behaviors. The documentation serves less to connect youth with social support and more to put a magnifying glass over their behavior. Instead of intervening with youth at any early age to prevent abuse, surveillance and criminalization only reinforces inequalities that produce violence.

While they do not excuse violence, anti-carceral feminists are skeptical of attempting to change cultural norms or resolve inequalities through legal means. "Message sending" or "symbolic" laws, like emergency-oriented policy, bestow policymakers with the unchecked ability to create 
any criminal law regardless of how counterproductive it is to serve survivors and deter abuse (Gruber, 2020, p. 106). In fact, criminal justice intervention often exacerbates the psychological, economic and social conditions that correlate to higher rates of gender violence. For example, in cases of intimate partner violence, survivors may share more economic, familial and emotional dependencies with their partner. Thus, punishing perpetrators can also directly jeopardize the stability of survivors, especially for poor people of color. Studies reveal that criminalizing abusive partners puts survivors at disproportionate risk of losing their home, child support, and citizenship (Gruber, 2020, p. 87). Criminal records can cause a chain-reaction of events that make it difficult to find employment or receive certain benefits. Imprisoned people also suffer physical traumas from attack dogs, strip and cavity searches, sexual assault, inedible food and overcrowding (Goodmark, 2021, p. 91). These measures further destabilize relationships and increase chances perpetrators will harm again.

\section{Anti-carceral feminisms}

As Dolores Juliano (2020) indicates in the Spanish context, "More than ten years after the implementation of a higher sentence for perpetrators of gender violence [in Spain], the number of femicides per year has nearly stayed the same" (p. 1). Even though lawmakers and mainstream feminists in both Spain and the US continue to push for harsher and harsher sentences and procedures, the use of criminalization to combat gender violence has proven ineffective time and time again. Anti-carceral feminists, such as Angela Davis, Assata Shakur and Ruth Wilson Gilmore, insist that we will not incarcerate our way to non-violence. In the words of Gilmore, "the criminal justice system does not have just moral faults but practical ones" (Kushner, 2019). Since the 1960s, black feminist prison abolitionists they have called not just for an abolishing of carceral systems but also an investing in public health, housing, education, employment and food programs (Kushner, 2019).

Dean Spade (2013) echoes black feminist prison abolitionists in his calls for tackling intersectional violence throughout population-level legal and administrative systems. The use of criminalization to combat gender violence suggests that we can amend harm by teaching race or gender consciousness on an individual, progressive-temporal basis (Spade, 2013, p. 1034). 
Instead, population control, as a vector of analysis, moves the focus from "discrete incidents or individuals" to a focus on "multiple systems that operate simultaneously to produce harms directed not at individuals but at entire populations" (p. 1035). Dean Spade's intervention suggests that the criminal justice system cannot be saved with reforms because removing bad laws and bad cops one by one does not attend to the racist, transphobic, patriarchal, ableist and anti-poor structure the prison system is built on and reproduces.

Mimi Kim has been a long-time activist who translates transformative justice theories into tangible practices. Co-founder of the US-based organization INCITE! Women of Color Against Violence (now known as INCITE! Women, Trans and Gender Non-Conforming People of Color Against Violence), Kim advocates for interventions that address the structural conditions that create more violence in marginalized communities of color. To reach such a goal, INCITE! believes in transformative justice gender violence models, rooted in indigenous practices ${ }^{4}$ and abolitionist social movements driven by people of color, that decrease stigma, shift community norms and center collective, community-based responses rather than state authorities. This may consist in using language like "person who caused harm" rather than perpetrator, abuser or offender or "supporting accountability" rather than "holding someone accountable". ${ }^{5}$ Communitybased strategies involve networks of friends, family and community members rather than police, child welfare, immigration control, civil courts or anti-violence organizations that work in collaboration with the latter institutions (Kim, 2020, p. 168).

Leigh Goodmark (2021) makes concrete suggestions for what a non-punitive accountability process may look like. According to Goodmark, the survivor should lead and initiate the process "allowing survivors to determine whether, when and how such processes should proceed" ( $p$. 95). Both parties should also be linked to resources before, during and after the processes. This model stresses accountability by involving meditators, family and community members. Involving the community and treating violence as a broad social issue rather than individual and

\footnotetext{
${ }^{4} \mathrm{Kim}(2020 \mathrm{~b})$ explains that indigenous practices of addressing harm and establishing justice have been "left unwritten, unrecognized, and largely erased by colonial and neocolonial histories" and "long precede the recent "discoveries" of transformative justice or restorative justice" (p. 314).

5 This first-person language is typically used in therapeutic settings and accountability-processes. For the purposes of this paper, use language from legal and professional settings (perpetrator, abusive partner, survivor, victim) given that it is the area I critique.
} 
idiosyncratic can lead to greater changes in cultural norms and provide both parties with support networks to heal (Goodmark, 2021, p. 95). Returning to Kim (2020a), non-punitive accountability models should be wary of restorative justice models ${ }^{6}$ that maintain strong ties with law enforcement: "Compared to strongly anti-carceral or prison abolitionist transformative justice, restorative justice has been confined, to a large extent, to its role as an alternative to the criminal legal system that also leaves that system intact" (pp. 169-170). Transformative justice organizations, like INCITE!, question the embeddedness of state-run public and nonprofit organizations, supposedly subscribing to restorative justice, with carceral architecture (Kim, 2020b, p. 314).

Leigh Goodmark (2020) states that distributional and rehabilitative policy rather than criminalization is the best method to change patriarchal cultures around sex and relationships. Goodmark (2020) identifies various effective pre-, during and post-violence interventions. Increasing the minimum wage, affordable housing, health care access, and free education all reduce stressors on relationships. Education programs around sex, sexuality, relationships and media literacy for teens and youth improve cultural logics around consent and healthy relationships. More regulation around coerced debit and unfair tax liability can hinder opportunities for economic abuse. Emergency funding for rental housing, food and transportation can provide a path to safety without involving the police. A mobile unit response unit with gender violence advocates can also de-escalate violence by meeting with victims and helping them to safety plan. Post-abuse strategies such as expanding employment opportunities, work readiness training, education grants and therapy can help prevent future violence for survivors and perpetrators (p. 93). The latter material supports can help survivors find safety and healing without involving the police, which historically have escalated violence (p. 72) and increased survivors' chances of economic ruin (p. 87).

Through the practices suggested above, transformative justice practitioners have operated with barely any financial support or credibility and yet survived thanks to strong political will and

\footnotetext{
${ }^{6} \mathrm{Kim}$ (2020b) explains that restorative justice has a complicated history but a review of nationwide restorative justice programs shows that they are "white dominated and law enforcement friendly" (p. 316). Whereas, transformative justice has more roots in indigenous practices and people of color abolitionist movements (p. 314).
} 
networks of care (Kim, 2020, p. 169). In a world where many people face a severe crisis of imagination and long-term visions, Mimi Kim (2020) illuminates an anti-carceral path forward:

Transformative justice offers a liberatory and emergent vision of justice that asks the everyday person to participate as a likely survivor of violence, a potential perpetrator of violence, and someone invested in a world liberated from violence in all of its forms. It renders the intervention of violence and its prevention as an everyday democratic act, one not reserved for authorities of the state but offering a meaningful role for anyone part of a family, a neighborhood, or a community (p. 170)

Kim's inspiring words remind us of the relevance of anti-carceral feminist interventions and provide the motivations and tools for debunking the myth of punishment as justice. In the next chapter, I will explore more of the historical significance of anti-carceral debates and how carceral feminism rose to power in Spain. 


\section{BACKGROUND- POST-FRANCO ANTI-CARCERAL SENTIMENTS IN CRESCENDO: THE RISE OF INSTITUTIONAL FEMINISM AND NEOLIBERAL GOVERNANCE}

In the previous chapter, I outline the rise of neoliberal ideology and carceral feminist logics worldwide. I include the work of anti-carceral thinkers to paint a counter-narrative to punishment as the de facto solution to gender violence. Additionally, I offer evidence-based preventive, emergency and rehabilitative intervention strategies that do not rely on criminal justice involvement. In this chapter, I shift to the historical genealogy of (anti)carceral debates in Spain to better understand how penal demands rose to the forefront of the mainstream feminist agenda. To do so, I examine the appearance of and justifications for (non)penal strategies in the post-dictatorship era. This historical background is essential for contextualizing the subsequent emergence of Law 1/2004 and The Yes Means Yes Law. This chapter does not capture the entire historical trajectory of post-Franco organizing nor the more specific conditions that shaped each law (which I will further outline in their respective chapters). Rather, the Background acts as an entry point to briefly describe the construction of institutional feminism in Spain and its insertion of carceral tactics to the mainstream.

\section{Anti-punitive demands in post-Franco organizing}

Several Spanish scholars (Uría-Ríos, 2009; Gil, 2011, Larrauri, 2007) historicize the sidelining of more radical Spanish feminisms by institutional feminism. Their work is key for assessing the temperature of (anti)carceral sentiment following the death of Franco in 1975 and the "ending" of four decades of state repression of feminist organizing. Early feminist groups and associations largely organized in secrecy through various local and regional networks in the early 1960s and 1970s. Movimiento Democrático de Mujeres (“Democratic Movement of Women”) organized clandestinely by infiltrating las Asociaciones de Amas de Casa y Hogar ("Housewives Associations") which were working-class neighborhood groups established during the Franco era with a conservative and religious focus. They brought taboo discussions about the general political situation and other topics like sexuality and gender roles to the larger community (Gil, 2011, p. 58). 
It was not until 1977 that the regional coordinators of those groups agreed to establish a National Coordinator of Spanish Feminist Organizations in order to better connect actions and public campaigns. The newly installed Coordinator organized assemblies in cities across the country ${ }^{7}$ that featured a plurality of feminist beliefs, the most dominant of which were socialist feminists, radical feminists and autonomous feminists. The main issues discussed throughout the 1970s were access to education, reproductive rights, sex work, divorce rights and amnesty for political prisoners (Gil, 2011, p. 59). Feminist participation expanded beyond the assemblies and a multitude of diverse feminist groups and collectives surged in universities, workplaces, schools, working-class neighborhood, political parties and the streets (p. 59).

Uría-Ríos examines two assemblies focused on gender violence entitled "Violence Against Women and The Penal Code" in Barcelona and "Domestic Violence Against Women" (1988) in Santiago. She also analyzes a journal and brochure against misogynist violence published by the National Coordinator in 1990. The meetings and brochure provide a glimpse of how different feminists approached the criminalization of gender violence. Interestingly, Uría-Ríos points to how higher prison sentences did not appear within feminist demands: "It was a generation that did not consider prison as a solution for social ills nor believed that carceral institutions were working as rehabilitation centers" (p. 123). Many feminists called for more investment in resources that would help women leave a violent situation such as unemployment benefits, professional development and free legal defense (p. 122). Feminists debated whether to use the law as a vehicle for addressing inequalities such as gender violence. Some expressed concern that it would give more power to a patriarchal criminal justice system and others thought it was an indispensable tool for amending Franco-era disparities in how the law criminalizes and protects certain populations.

Silvia L. Gil (2011) pinpoints debates about Marxism's role in the feminist movement as a catalyst for the divide between reformist and separatist approaches. Gil states that the Democratic

\footnotetext{
7 Some of the main assemblies included: Las Jornada de Liberación de Mujer (1975), Jornadas Catalanas de la Dona (1976), Asamblea de Mujeres de Bizkaia (1977), Jornadas Feministas de Euskadi (1977) and II Jornadas Feministas Estatales de Granada (1979) (Gil, 2011, p. 58).
} 
Movement of Women urged other feminists to focus on Marxism and class struggle as an explanation for sexual division of labor. This sparked many conflicts over whether capitalism causes patriarchy or whether patriarchy is its own separate and specific struggle (p. 61). The reformists embraced Marxism for underlining womanhood as a politically and socially constructed category that can be undone through legal equality measures. In contrast, the separatists rejected Marxism for overlook of gender and adopted a sexual difference model that argued women and men are ontologically different, and, for that reason, feminists should not focus on making differences disappear but revalorize feminine characteristics socially and culturally positioned as inferior (p. 62). The reformist feminists sought representation in the electoral system to create large social reforms. Meanwhile, separatist feminists critiqued reformists for relying on a masculine, unjust system and believed that female freedom lied in autonomy and construction of alternative forms of care and life (p. 62).

The reformist and separatist divide unfolded into conversations about the state's role in resolving gender violence. Uría-Ríos (2009) notes how feminists on both sides questioned whether: prosecution could provide healing; police could escalate violence; and/or courts could strip survivors of consent during legal proceedings (p. 123). Broadly-speaking, feminists were far from naive about the capacity of prisons to rehabilitate and the possibility of their demands to create harsher punishments. Nevertheless, the majority favored a legal approach to gender violence because of the law's capacity to define gender violence and address its importance as a widespread and serious social issue (Larrauri, 2007, p. 69). Even those who were most critical of the criminal justice system believed that the state law, despite its biases and faults, bears a certain legitimacy to power that can (if anything, symbolically) send a message that gender violence is not acceptable behavior. They were also aware that codifying crimes into the penal code allows for the collection of official statistics that can further substantiate gender violence as a large-scale societal problem (Larrauri, 2007, p. 59).

Larrauri (2007) qualifies her analysis with the reminder that we cannot blame feminists entirely for the gender violence punitive turn. She writes, "denouncing the importance of a social problem and the inequality that operates in the penal system is not synonymous with asking for more penal intervention" (p. 70). Feminists organizing after the dictatorship did not believe that the 
criminal justice system was the one-stop-shop for solving gender violence. Rather, the 1970s feminist agenda called for a mixture of punitive and non-punitive demands, but the former strategies gained more momentum due to the institutionalization of feminism and the rise of neoliberal governance.

In 1982, Partido Socialista Obrero Espanol (The Spanish Socialist Workers' Party) gained control of the government and established the Instituto de la Mujer (Women's Institute) (Gil, 2011, 107). Many former reformist activists from the Franco era arrived to governmental positions of power and started to rapidly pass new women's rights legislation. ${ }^{8}$ Previous debates surrounding the approval of the constitution in 1978 solidified reformist feminists' entrance into bureaucratic power. During the democratic transition process, feminists overwhelmingly criticized the new Constitution for not taking any specific measures to amend gender inequality or negotiate with feminist groups. Reformists argued that the Constitution, despite its faults, was an unquestionable achievement and necessary measure after many long years of the dictatorship. Separatists, on the other hand, called for voter abstention arguing that the constitution was anti-democratic, sexist and would close the door on future progressive legislation (p. 106). In the end, reformism became the most popular option, which curbed more radical groups who were firmly against it, from future participation in the electoral process. Gil (2011) recalls how this move felt like a form of "blackmail for those who did not feel represented in the reforms that they were putting in place" (p. 106).

\section{Institutional feminism and the inception of $1 / 2004$}

The institutionalization of feminists into power was at the same time a triumphant and troublesome moment. Throughout the 1980s, the feminist movement faced many new changes in the 80s: collectives began to disperse, interests began to diverge, and overarching ideologies entered crisis (one being the subject of feminism) (Gil, 2011, p. 108). These cracks made it harder to intervene against institutional feminists, making their agenda more partisan, especially given that they rarely consulted other feminist groups when planning their initiatives (Gil, 2011,

\footnotetext{
${ }^{8}$ Legalization of anti-contraceptives (1977); full divorce rights (1977); legalization of abortion (1985) (Gil, 2011, p. 66)
} 
p. 107). The Women's Institute professionalized gender violence services by funneling resources into "para-institutional" organizations that respond to women seeking assistance (Martinez, 2017 , p. 339). Far from the most radical thinkers of the feminist movement, para-institutional organizations play both mobilizing and service-provider roles in that they generate national statistics, organize November 25 demonstrations and lobby for legislation to political parties (Martinez, 2017, p. 340).

Gil (2011) explains that "institutions are not bad within themselves (they are not unchangeable entities but constructions of power); what is in play then is the meaning of 'making-institution"' (p. 109). For institutional feminists, making-institution has meant prioritizing the voices of specialists (femocrats), abandoning critical and plural stances, and embracing an evolutionary logic of equality where progress is linear. Organizing from institutions also meant constructing demands according to budget, long-term strategy, political convenience and close-door deal instead of direct-action, participatory democracy (p. 111). For this reason, Gil (2011) postulates that the problem is not the institution itself but what institutionalization "makes visible and invisible, say-able and un-sayble, inside and outside, what is in the margins and what is in the center" (p. 110). Institutional feminists substituted "the voice of the movement for the voice of the institutions" producing a crisis of legitimacy based on the meaning of feminism and the institution's transformative capacity (p. 110).

By the 1990s, the relatively-more unified feminist movement of the 1970 s began to decentralize into smaller groups comprising of gays, lesbians, queer, transgender people, anti-militarists, autonomists, sex workers, precarious workers, anarchist okupas, migrants and university students (Gil, 2011, p. 68). They were not focused on orchestrating a mass-movement or taking power from the state but rather questioning the structures, subjects, identities and methods put forth by traditional institutional feminism. They embraced ethics such as: irreducible multiplicity, direct action, power from the bottom, new socialities, counter-discourses and organizing from desire (p. 71). The dispersal of feminist entry-points and demands had its costs. According to Gil, "there did not exist any systematic critique to institutional feminism, from the feminist movement nor from theoretical academic production" (p. 115). Therefore, the diverse and vibrant conversations happening among the wider feminist movement did not more influentially filter into 
higher-level policy considerations including those involving gender violence.

By the latter-half of the 1990s, neoliberalism began to shake Western Europe and punitive gender violence policy became more politically auspicious than ever. The left and right allied around criminalization: the left could make good on a promise to respond to feminists' demand for accountability and the right could use gender violence law as a medium for expanding criminalization. Punishment became an attractive strategy for both camps to quickly signal to the public that the government was finding "solutions" to a growing unrest in society about the unacceptability of gender violence. Institutional feminists rallied behind the political convenience of neoliberal gender violence interventions leading up to Law 1/2004.

Institutional feminists use two main rhetorical strategies in order to increase sentences and tighten prosecutorial procedures. First, institutional feminists brand critics of criminalization as rape apologists who do not take gender violence seriously. They typically compare gender violence prison sentences with other sentences like animal abuse or graffiti in order to show how lightly the justice system treats gender violence (Larrauri, 2007, p. 56). Institutional feminists argue that anyone who critiques increasing gender violence sentences does not take the pain of victims seriously (p. 68). This proved to be a convincing strategy to lawmakers on both sides who wanted to be "tough on crime".

Next, institutional feminists purport survivors who do not cooperate with the criminal justice system do not know what is best for them. While they do not attribute the causes of abuse to women, institutional feminists blame women for the continuation of abuse if they decide not to report. Throughout 2008, The Women's Institute released publicity campaigns with slogans such as mujer denuncia ("woman, report"), mujer acude ("woman, leave"), tu silencio es complicidad ("your silence is complicity"), and mamá hazlo por nosotros actúa ("mom, do it for us, act") (Larrauri, 2007, p. 66). Several direct service organizations harshly criticized the advertisements for taking the focus off the wrongdoing of the perpetrator ${ }^{9}$ (p. 68). Ultimately, institutional

\footnotetext{
9 This reflects the larger attitudes of social workers serving survivors who express their deep ambivalence with criminalization given its unignorable risks to survivor safety. Social work best practices only encourage involving the police in exceptional circumstances and at the direction of the survivor who is majority of the time more concerned with safety than retribution (Larrauri, 2007, p. 68).
} 
feminists uphold very normative gender violence narratives and ignore more complicated questions about why many survivors avoid the criminal justice system in the first place.

Institutional feminist rhetoric filtered into Law 1/2004 and The Yes Means Yes Law through its definitions of gender and sexual violence and its punitive "resolutions". The evolution of institutional feminism exhibits how early anti-fascist sentiment became co-opted by tough-oncrime values that privileged the police and punishment. As Uría-Ríos describes, feminists were extremely wary of relying on the police after just facing the brutalities of the Franco regime and overwhelmingly agreed that courts and police could not be the sole strategy but rather one aspect of a comprehensive multi-system plan. The institutionalization of feminists into power in the 1980s combined with the adoption of neoliberal social governance shifted mainstream demands toward criminalization. In the next chapter, I will further consider the more immediate circumstances that led to the Organic Law 1/2004 as well as its specific punitive designs and resistances therein. 


\section{ANALYSIS- LAW 1/2004 AND THE YES MEANS YES LAW: POLICING AND PUNISHMENT AS GENDER VIOLENCE “JUSTICE”}

In 2014, UN Women, The World Future Council and The Inter-Parliamentary Union named Law $1 / 2004$ as "one of the most effective laws worldwide in combating and eliminating sexist violence" (Ministerio de Igualdad, 2017, p. 2). Fast-forward to 2020 and the Minister of Equality, Irene Montero, broadcasted to the Spanish public that the Organic Law for Comprehensive Guarantee of Sexual Freedom (The "Yes Means Yes" Law) would turn Spain into the "most safe" country for women and prevent that "the rights of women ever are lost again in a dark alley". She proclaimed that Spain would become an "international reference" for the defense of equality (Martín J., 2020). While femicides have decreased rather consistently since 2003, statistics show that 74 percent of those 1000 victims did not report to the police and that foreign/migrant women were disproportionately affected (Consejo General del Poder Judicial). These strikingly high numbers, which have traditionally been used by to insinuate fewer women would have died were there more police involvement, also warrant further critical analysis of whether victims trust the criminal justice system to properly assist them. Given that there has yet to be a systematic critique from institutional feminists and scholars of the punitive turn in gender violence legislation put forth by institutional feminism, one must question whether Spain's so-called trailblazing efforts to eradicate gender violence have worked for all, especially those on the margins of society.

The previous chapter contends that the championing of criminalization by institutional feminists invited compromise with the conservatives and was par for the course for a punitive gender violence legislation. Here, I take a closer look at each law to question whether its punitive creed is indeed as effective as it claims to be in decreasing instances of gender violence. I introduce each law as an object of legal discourse and explain the socio-political conditions that led to their respective emergence. Then, I conduct a genealogical-critical discourse analysis (Anais, 2013) using the Fairclough (1989; 1995) model of textual (description), processing (explanation) and social (critique) analyses, infused with insights from the feminist (Lazar, 2007; 2018) and legal (Rajah, 2018) fields. I read along and against the legal categories of "victim" and "justice" focusing on the following interrelated Fairclough analysis elements: 
a) Description, where I describe: how the law defines the categories; how its scope relates to the laws' framing of gender violence as a problem; and, how it relates to the measures taken to resolve gender violence

b) Explanation, where I interpret: how the law's justifications relate to larger theories about globalizing punitive trends in gender violence as well as the specific Spanish context

c) Critique, where I explain: how the law's exclusionary frameworks and punishment technologies lead to racial and gender disparities in victimization and incarceration; and how anti-carceral feminist resistances disrupt hegemonic gender violence perspectives that suggest police and prisons are indispensable to justice

Following my analysis of victim and justice, I highlight several expressions of resistance to the carceral measures in Law 1/2004 and The Yes Means Yes Law. As you may recall, CDA and genealogy understand discourse and social practices as dialectical, wherein every action necessarily involves resistance. The refusal of certain collectives to carceral feminism shows norms are a site of constant struggle and are not the product of an all-powerful and unchanging entity.

\section{Law 1/2004: the ground-zero for gender violence punitivism}

\section{Context}

The Background section focused on the larger socio-historical conditions post-Franco that led to the institutionalization of feminism and the punitive take in Law 1/2004. This brief section describes the more immediate political context that led to the passing of Law $1 / 2004$. It focuses on key domestic and international focusing events and political landscapes that allowed Law $1 / 2004$ to enter the public debate.

Law 1/2004 unanimously passed the Spanish House of Representatives in April 2004 and officially came into effect in December 2004. Prior to its enactment, there were several laws that specifically addressed domestic violence. The first 1989 domestic violence law shifted abuse from a misdemeanor punishable by a fine to a felony punishable by jail time. It narrowly addressed one-time and daily physical battering between conjugal heterosexual couples. The 
law was modified several times in 1995, 1999, and 2003 (Larrauri, 2007, p. 60). The 1999 version is well known for expanding the definition of domestic violence to include psychological abuse and abuse between ex-romantic living partners (p. 61). Beyond this major conceptual change in 1999, each other modification mainly focused on progressively toughening prison sentences and criminal procedures (p. 60). Avoiding the tougher political gymnastics of structural change, lawmakers pacified feminist complaints by making quicker, symbolic changes through criminalization policy. In the words of Larrauri (2007), lawmakers were "pretending to find a solution when we still do not exactly know the problem" (p. 65).

The public's appetite for government action on gender violence can partly be attributed to several high-profile femicides. The 1997 case of Ana Orantes particularly shocked the public because only days prior to her ex-husband gruesomely burning her alive, she appeared on television describing the abuse she suffered (Minder, 2020). The fact that Ana Orantes had already separated from her partner and informed a wide audience flipped common myths that blame women for not leaving abusive situations. Her murder shifted common attitudes that made people feel they were immune to maltreatment because of their stronger moral character and self-worth. Rather, many witnessed for the first time on live television, a woman whose separation from her abuser did not keep her safe. ${ }^{10}$ Orante's murder acted as an inflection point that moved gender violence from a private discussion to a public reckoning with the state's role in providing access to safety.

International pressure for gender violence legislation also began to mount throughout the 1990s. The United Nations held a highly influential conference ${ }^{11}$ in Beijing in 1995 that for the first-time defined gender violence as different from domestic or familial violence. According to an "Action Plan" drafted at the conferences, gender violence is described as physical, sexual or psychological violence driven by the inequality between men and women. With the support of a respected international institution like the UN, feminist groups felt emboldened to draft a comprehensive gender violence law. Feminists were determined to shift the government's

\footnotetext{
${ }^{10}$ As many experts remind us, leaving is the most dangerous time because of its potential to escalate violence (National Coalition Against Domestic Violence).

${ }^{11}$ Formally named United Nations Fourth World Conference on Women 1995- Beijing, China
} 
framing of violence against women as a private, familial matter to a public, structural issue that necessitated the cooperation of more government branches than just the judiciary.

Then in 2002, nine national feminist organizations came together to form the Network of Feminist Organizations Against Gender Violence. ${ }^{12}$ The Network presented their collective proposal for a comprehensive gender violence bill that then the United Left sponsored and introduced in Congress. The bill featured various health, economic, educational and judicial objectives but also some heavy-handed new punitive measures (El País, 2002). The President at the time, Jose Maria Aznar of the conservative Popular Party (PP), promised to various feminist collectives during his 2000 campaign that he would pass a gender violence law. In the end, the bill failed 165 to 151 due to the decisive votes of members of Aznar's own party. Feminist groups in attendance allegedly heckled the members of PP in the auditorium and were escorted out of the building (Nogueria, 2004).

Aznar stood alongside his party members and criticized the law for its "tepidity" and lack of "concrete measures". Aznar referred to the fact that the law did not: increase prison sentences, strengthen restraining orders, and create a special "surveillance body" for stalking cases (Libertad Digital, 2002). Zapatero, on the other hand, praised the bill for its focus on expanding women's rights, prevention and education mechanisms and improving social and economic measures. It was not lost on Zapatero, who proceeded Aznar, that the carceral question was the only roadblock between him and passing gender violence legislation. Zapatero and his party members were eager to deliver on campaign promises especially after the embarrassing defeat was widely broadcasted on live television and closely followed by wide audiences. ${ }^{13}$ The media coverage cemented gender violence into the public conversation and emboldened Zapatero and the left to quickly change course in 2004 and adapt to PP's punitive appeals (Libertad Digital, 2002).

12 Member organizations: Mujeres Progresistas, Mujeres Separadas y Divorciadas, Asistencia a Víctimas de Agresiones Sexuales, Mujeres Juristas (Themis), Enclave Feminista, Comisión para la Investigación de Malos Tratos, Mujeres Vecinales de España, Asociación de Medios de Comunicación y Fundación Mujeres.

${ }^{13}$ According to the CIS Barometer, public awareness of gender violence increased 277 percent from September to August 2002, while representatives debated the bill (Varona-Gómez, Norman-Gabarrón, 2015, p. 24). 
Zapatero responded to the political urgency of maintaining his credibility with feminist groups by passing a very punitively focused Law $1 / 2004$. In the rush to pass something, Zapatero sacrificed a slower yet distributional and preventative politic for an emergency and neoliberal politic. The future 2004 legislation would include important structural changes to the health, economic, social welfare, and educational systems that feminists would praise as important answers to demands circulating since the 1970s. However, to the dismay of those same early radical feminists, it still would rely more heavily on bolstering prisons and police than the previous version of the bill. It would also only limit gender violence to the context of affective relationships which both institutional and anti-carceral feminists would denounce.

It is concerning why the right so fiercely insisted on the criminal justice system when it was widely understood that criminalization did not deter violence. The General Council of the Judiciary (CGJP) itself published a study indicating the inefficacy of criminalization strategies just one year after the passing of Law 1/2004. According to the 2005 report, only 19.8 percent of murdered women reported abuse. Strikingly, of those 19.88 percent who were murdered, 5 out of 10 possessed active protection orders (Larrauri, 2007, p. 64). This data suggests not only a mistrust in the penal system but also a failure of it to protect women even after intervening. Overall, the left made a calculated political decision to compromise on criminalization in exchange for passing some gender violence legislation. While lawmakers appeased their majority voting blocs, they did confront the material toll the punitive compromises would have on marginalized populations.

\section{Analysis: victim and justice}

Next, I analyze the terms "victim" and "justice" where I evaluate what Law 1/2004 intends to accomplish, for what reasons and by what measures. I find how the law lives up to its promises based on how it presents: what a victim experiences, who can be a victim and how harm is amended. Each analysis contains the three Fairclough dimensions: textual, explanatory and critical. 
Victim: According to Law 1/2004, a victim of gender violence is someone who experiences "physical and psychological violence, including aggressions against sexual freedom, threats, coercion and deprivation of liberty" (BOE n 313, 2004, art. 1.3). It excludes other forms of sexual violence, from rape to harassment, stalking, sex trafficking, gender mutilation, forced marriages, anti-trans violence and teen dating violence. The Law describes victims of gender violence as cis women who experience abuse within a current or former conjugal, heterosexual relationships with cis men:

[Gender violence] is exercised against the latter [female victims] by individuals who are or were their spouses, or individuals who have been in relationships with them although not necessarily living under the same roof (art. 1.1)....[abuse] consists of the aggressions suffered by women as a consequence of the sociocultural conditions that act over the masculine and feminine genders, positioning the feminine in a subordinate relation to the man. (Motivation Statement, I)

Therefore, victimhood belongs exclusively to cis women in affective relationships with cis men and excludes cis men, trans people and queer people. It restricts gender violence to the nuclear heterosexual family and away from other sorts of violence that happen in nonpartnered realms. Some judges have even been hesitant to apply Law 1/2004's to teen dating violence cases because the partners are not working towards "a future project together" or because there does not exist a "community of love and freedom" (SAP Cordoba 69/2006 9 of February \& SAP Alara 80/2006 4 of Abril, JUR 2006/189373). This limited definition of gender violence conflicts with the more abroad UN definition highlighted in the Law which suggests gender violence is not a "private" problem but exists in the partner, social and workforce spheres (Motivation Statement, I).

The definition also examines gender inequality from a binary and essentialist lens. Law 1/2004 explains the cis women are disproportionally more likely to become victims of gender violence solely because of gender inequality: "It [gender violence] concerns violence toward women for the fact of being one, for being considered, by their aggressors, of lacking minimal rights to liberty, respect and agency" (I). The predicates victimization on gender alone, positioning it as superior to other identities that shape one's specific experience with violence. Hidden in the thick of the law, there lies how violence occurs differently for marginalized women: 
The law considers the special situation of women, who for their own personal and social circumstances, can suffer a greater risk of gender violence or greater difficulties to access services provided for in this Law, such as those who are minorities, immigrants, those who face social exclusion, or women with disabilities. (art. 32.4)

The law acknowledges how marginalized women are at greater risk of victimization and face more difficulties accessing services. In various other clauses focused on education prevention (art. 7k), judicial assistance (art. 17) and integration of services (art. 32f), it promises to ensure that "all victims" of gender violence regardless of their personal or social circumstances, have their rights, needs and demands fulfilled. This article does not expand on how they will amend for disproportionate rates of violence and access to care.

The Law's understanding that victims are cis-heterosexual women who experience violence in the nuclear family home on the sole basis of gender speaks to the trajectory of the feminist movement. During the dictatorship, the Catholic-Franco regime instructed girls and women how to be good housewives and mothers in service of the nation through an institution called Sección Femenina ("Female Section"). The 1970s feminist movement sought to counter the construction of the woman-housewife-mother subject by targeting their campaigns at "liberating" them from their dominated position. As a result, refusing this narrow experience of womanhood became a unifying identity for the feminist movement (Martinez, 2017, p. 331). Through the 1980s and 1990s, some feminists kept questioning the woman-housewife-mother for its partiality and the exclusions it produced (Martinez, 2017, p. 335). Transgender, lesbian, queer and migrant movements questioned the stability of categories (Gil, 2011, p. 132) and more successfully visibilized their experiences with police violence, especially against trans sex workers (Gil, 2011, p. 167).

The implosion of the woman-wife-mother subject of feminism led to a crisis of identity for some feminists who still claimed the need for one singular subject. Eventually, institutional feminists found the common experience to be the vulnerability all women suffer under the patriarchal system (Martinez, 2017, p. 339). Since the release of the first anti-gender violence ads in 1998 until more recent ads, The Woman's Institute has stuck with the imagery of the silent, mother and domestic woman as its primary subject (Núñez-Puente \& Fernández-Romero, 2015, p. 275). 
While trans, queer and migrant collective contested the normativity of this subject, institutional feminism surged in power with neoliberal ideology and silenced the realities of these groups (Gil, 2011, p. 131). This sidelined other feminist movements from intervening in major gender violence discussions, such as the construction of a meaningfully intersectional Law 1/2004. Even prominent anti-carceral gender violence scholars (Larrauri, Laurenzo-Copello, Maqueda-Abreu, Juliano, Bodelón-González) in Spain, who are critical of the vulnerable-subject, support the idea that cis women are the subjects of gender violence. Their claim is that people in a relationship with the same gender do not face gendered power dynamics, and hence, cannot be victims of gender violence. ${ }^{14}$

Ultimately, Martinez (2011) argues that Spanish gender violence discourses on the victim are clear: they are "passive, submissive, powerless, helpless, dependent, lacking in agency, vulnerable" (p. 341). Núñez-Puente \& Fernández-Romero (2015) support this critique in their study on victim representation in governmental advertisements. The researchers state that the gender violence subject is portrayed as a silent, female, mother who experiences severe, psychological and physical violence in the domestic and labor spheres and finds agency only through reporting to the police and leaving the abusive situation (Núñez-Puente \& FernándezRomero, 2015, p. 275). They conclude that this "aestheticized" subjecthood is politically productive because it backs the traditional narrative of the horrified, female victim and evil, male victim (Núñez-Puente \& Fernández-Romero, 2015, p. 280). The association of female vulnerability to violence takes center stage in Law $1 / 2004$, whose first line reads that gender violence "reveals itself as the most brutal symbol of the existing inequality in our society" (Motivation Statement, 1). Because inequality, discrimination and domination are associated with violence, "every woman in a patriarchal system suffers from violence, is vulnerable, is open to be hurt, is a (potential) victim" (Martinez, 2017, p. 343). The link between vulnerability and

\footnotetext{
${ }^{14}$ Larrauri (2007) believes that gay men cannot be victims of any sort of gender violence, but gay and bisexual women victims of violence perpetrated by cis men in the labor or social realm.
} 
womanhood reinforces traditional conceptions of femininity as well as masculinity (Martinez, 2017, p. 343).

In a fascinating critique, Martinez (2017) examines how Law 1/2004 also reinforces female vulnerability through the inclusion of its vulnerable people clauses. While the Law allocates women as its target population, it stipulates that "any especially vulnerable person who lives with the perpetrator" may also be considered a victim of gender violence. Comparing "especially vulnerable people"15 to "women" is concerning because "the vulnerability of "especially vulnerable people' must be proven while women's vulnerability is assumed de facto" (Morillas, 2009 as cited in Martinez, 2017, p. 344). This creates a hierarchy between women: those who liberate themselves from vulnerability by not experiencing violence or leaving an abusive situation and those who have submitted to it (Martinez, 2017, p. 344). By obscuring the structural factors that cause differentiated vulnerability, gender violence policies like Law 1/2004 implicitly serve the white, cis-heterosexual woman (Richie, 2000). Aya Gruber (2020) asserts that neoliberalism uses moral panic as a political strategy because it thrives under the belief that "outrageous behavior [is] committed by a discrete and deviant group" (p. 287). This portrait redirects attention "away from the structural, social and institutional accounts of harm and toward punishment" that make people of color, queer, trans and other marginalized people more likely to experience violence (Gruber, 2020, p. 287).

Law 1/2004 privileges the white, cis-heterosexual woman subject through by not developing meaningful interventions that would improve marginalized peoples' access to services. Lisa Duggan (2003) discusses how contemporary neoliberal ideologies, focused on flattening differences, filter into NGO policy language to create a "one-size-fits-all" model. She argues that by developing symbolic identity categories, white activists isolate marginalized peoples' concerns without adopting the core of their perspectives in policy planning (pp. 44-45). One key example is how Law 1/2004 endorses this neoliberal-style of policymaking is how it mandates victims to interface with the criminal justice system to be "accredited as a victim" and access

\footnotetext{
15 The definition of vulnerable people is not clear, but Larrauri (2007) notes how it has been applied to co-living mothers, daughters or certain (ex)romantic male partners.
} 
rights to no violence." 16 It requires that victims seek a protection order or another form of official judicial order, such as a report from the district attorney, to seek victim status (art. 23). Gil (2011) notes how white and documented women consistently advocate for more police investment while sex workers, trans and undocumented people plead for the contrary (p. 165). White women's greater trust in the police is fundamental to the ideal victim narrative which alleges that victims are vengeful and satisfied with their victimizer's incarceration (Gruber, 2020, p. 100). In this sense, the normative victim justifies punishment as a medium for a victim's protection and healing.

Justice: While interrogating the term "victim", I point out how Law 1/2004 poses gender violence as a structural problem (even if that vision does not come to fruition in its measures). Law 1/2004 reasons that due to the structural nature of gender violence, the state's response must be "comprehensive" and "multi-disciplinary" (Motivation Statement, I). The law sums up its planned interventions as the following:

The scope of the law covers both the preventative, educational, social, assistance, and aftercare aspects for victims, as well as the civil regulations that affect the family and co-living environment where aggressions primarily occur...Likewise, the punitive response, that all instances of violence deserve, is vigorously addressed in the Law's regulations. (Motivation Statement, I)

Law 1/2004 positions its restorative measures at the forefront of its plans drawing attention to its importance and its determination to respond to early feminist demands. Nonetheless, the Law does not specify funding streams for its rehabilitative interventions, and more than two-thirds of its measures are dedicated to the criminal justice system. The implicit essentiality of punitivism comes to the light with the use of the word "deserve" at the end of the description where it paints criminalization as a logical and commonsensical response to any act of gender violence. Later in the Motivation Statement, the Law reiterates its commitment to "give a firm and robust response and show its firmness through specific criminal offenses" (III). The Law claims to act

\footnotetext{
16 "Rights to no violence" allow victims to access free counseling, free legal assistance, unemployment insurance, paid-time off, job-location changes, work readiness training, cash assistance and affordable housing. Right-to-noviolence reasons that gender violence is a form of discrimination and structural violence based on gendered norms and social values that prevents women from fully participating in society (Larrauri, 2007, p. 85). Positive rights are more scarce, especially in neoliberal democracies because they demand economic and political redistribution often to minorities.
} 
in the name of all women by assuming their unitary desire to harshly punish their perpetrators. It positions the criminal justice system as a legitimate and unbiased institution that can satisfy victims' desires by establishing and carrying out criminal offenses. All in all, punishment stands as the main medium of amending wrong or doing "justice".

This vision of justice-as-punishment translates to the Law's higher sentences that increase the penalties for: physical abuse from 2 to 5 years in prison (art. 36); psychological abuse (that does not cause injury) from 6 months to one year in prison (art. 37); and coercion (art. 39) and violation of a sentence (art. 40) from 6 months to a year. Additionally, it creates new penalties for: threats worthy of 6 months to a year in prison (art. 41) and sexual harassment punishable by house arrest (art. 41). The increase of sentences mirrors the upward trend in gender violence criminalization since the 1980s. In the first 1989 domestic violence law, the penal code considered battering a misdemeanor worthy of 1 to 30 days in prison. By the third reform to the same law in 2003, battering became a felony punishable by three months to a year in prison (Larrauri, 2007, p. 60).

In addition, Law 1/2004 enforces different punishments for violence against co-living (ex)romantic female partners than for other "especially vulnerable people". For example, one can face anywhere from 3 months to a year for threats or psychological or physical abuse (without injury) against any member of the family or vulnerable person. However, the same person can face up from 6 months to a year in prison for threatening a (ex)romantic female partner (Title IX). Between 2005 and 2009, criminal judges published over 200 questions about the constitutionality of Law 1/2004. In the end, the Supreme Court declared that it was a form of constitutional "positive discrimination" because it addresses the greater victimization of women and helps facilitate "equality" (Larrauri, 2007, p. 117). The verdict of the case provides more context for how the law reasons prosecutorial rules, in favor of women, can amend the harm disproportionately done to women. In other words, punishing men more harshly will rectify past wrongs where men were not punished as often and will encourage men not to commit more future violence. 
Just like Law 1/2004 claims that it can hold perpetrators accountable through criminalization, it assumes it can give victims access to safety and healing through "protection". In the preliminary chapter stating its main principles, the Law pledges to "strengthen the current criminal and procedural framework to ensure comprehensive protection, from the moment of prosecution, for victims of gender violence" (art. 2f). The Law's definition and approach to protection is contingent on the prosecution of the perpetrator. The principles only apply the term protection in conjunction with the criminal justice system, and it does not arise within other clauses focusing on economic, social and educational mechanisms. From this viewpoint, the victim is unsafe with solely rehabilitative measures, and the police are an absolute necessity for the victim's security. Essentially, the new procedural reforms are meant to speed up prosecutorial processes and reach a speedy criminal conviction:

Assure the alleged aggressors right to due criminal process without reducing the legal capacity this law provides for more immediate and efficient protection of victims, such as resources that prevent revictimization and escalation of violence. (Motivation Statement, III)

The bill promises to reduce victimization and retaliatory violence, but it still poses conviction as the best answer to survivors' pain and protection from future violence.

The logic of police as protectors arises in the Law's tightening of court procedures. ${ }^{17}$ First, judges or third parties may file protection orders, deeming that victims must stay away from perpetrators, regardless of the danger level or the victim's consent (art. 49bis). If a male perpetrator breaks this order, with or without the women's consent, they are subject to time in prison (art. 40). Second, it establishes obligatory no-drop prosecution, which makes it mandatory for the survivor to follow through with a case after reporting (art. 44). In some cases, a victim may even face punitive consequences, such as jail or misdemeanor, for failing to "cooperate" with law enforcement (art. 463) or for giving a "falsified" report (art. 456) or testimony (art. 458). Lastly,

\footnotetext{
17 It is important to mention that autonomous communities also create their own unique carceral stipulations. As such, Carceral tactics may expand beyond national legislation and the purview of this analysis. For example, Andalucia requires victims to file a criminal complaint in order to access medium and long-stay shelters (ValanzuelaVela \& Alcázar-Campos, 2019, p. 7).
} 
the Law prohibits any mediation or restorative justice model regardless of severity of violence (art. 44). ${ }^{18}$

The creep toward punitivism has resulted in a complex gender violence system that features both restorative and carceral interventions. The mixed demands embody the contestation between early 1970s feminists who insisted on holistic demands and the rising, punitive institutional feminist agenda. Aya Gruber (2020) links the entanglement of carceral and noncarceral policies to a more common occurrence in other state gender violence systems, where criminalization tends to hide behind structurally restorative initiatives. Speaking from a US context, Gruber explains that, despite their evenly distributed appearance, carceral aspects greatly outweigh and are even integrated into restorative interventions in neoliberal social policy. This coincides with the Spanish context in which the criminal justice budget has steadily increased since 2000, only seeing a slight decrease from 2011 to 2014. Meanwhile, social welfare programs have experienced much more turbulent budget changes with new political administrations (Expansión, n.d.).

International institutions, like the UN and EU, promote similar punitive approaches that stress the importance of reporting and "rapid and effective" police and court responses. The 1993 UN Declaration for the Elimination of Violence Against Women called for the establishment of penal sanctions to:

Punish and repair the wrongs inflicted on women who are subjected to violence; they must be given access to the mechanisms of justice and, in accordance with the provisions of national legislation, to fair and effective compensation for the damage they suffered. (Article 4d)

Mirroring Law $1 / 2004$, there is a vision of accountability and healing that starts and ends with the survivor calling on the state for protection and criminal sanctions. Other resolutions include similar interpretations such as the Recommendations of the 1979 UN Convention Against the Elimination of All Forms of Discrimination against Women and the UN Declaration (signed by most European countries). Debra Bergoffen (2012) substantiates this assessment in her

\footnotetext{
${ }^{18}$ Feminist organizations have long resisted restorative justice models because they argue mediation treats both partners as equal partners which they argue does not exist in abusive relationships with power and control dynamics (Mimi Kim, 2020, p. 169).
} 
observation that UN conventions position women "needing special attention and identifying the special protection they need with the special protection given to children establishes an uncomfortable analogy between women and children" (p. 25).

The institutional stance that protection and punishment is a facilitator of equality reinstates traditional stereotypes of woman as passive, submissive and helpless. This narrative arises in Law 1/2004's measures, such as automatic no-contact order, no-drop prosecution, and protection orders with/out victim's consent, that bypass the victim's desires. Given that those measures lead to retaliatory violence and revictimization (two things Law 1/2004 promises not to do), Law 1/2004 does not empower women to heal on their own terms. As I mention in the Theoretical Praxis, police involvement can destabilize a survivor's economic, familial and physical well-being. Larrauri (2007) argues that the idea that we will incarcerate our way to equality is extremely tenuous (p. 56). Although the intricacy of carceral and non-carceral interventions makes it difficult to measure the effectiveness of the criminal justice system, studies (Xie \& Lynch, 2017; Novisky \& Peralta, 2015) show that any deterrent effects of gender violence systems come from "material aid, social welfare, and rehabilitative parts of the process" and co-existing punitive policies only dull their effects (as quoted in, Gruber, 2020, p. 90).

Martinez (2017) intervenes by troubling the binary of the vulnerable/non-vulnerable subject by asking us to acknowledge "other forms of agency and to provide the conditions for the development of actions in a situation of vulnerability" (p. 346). She makes room to consider how survivors make calculated decisions every day to determine what will best keep themselves and loved ones safe. Outside of this binary, there is more possibility to see how marginalized people assume their agency in other ways that do not involve the police. While Law 1/2004 bars any mediation model (art. 44), anti-carceral scholars (Goodmark, 2020; Kim, 2020), mentioned in the Theoretical Praxis, indicate that non-punitive models can allow survivors to come face-to-face to those that harmed them, hear accountability for their actions and come to community agreements. Transformative justice models prove there are ways to keep a safe and empowering space that allows survivors to heal on their own terms.

\section{Resistances to Law 1/2004}


"We do not desire a vengeful feminism, we simply desire equal, respectful, and healthy relationships" (Pineda, 2006).

In March 2006, more than 200 activists, scholars, and professionals signed a manifesto in El País critiquing the construction of the victim and the vision of justice in Law $1 / 2004$. The authors critique the law for presenting women as voiceless and men as dominating, and hence, naturalizing socially and culturally constructed characteristics to gender. Instead of simplifying the causes of abuse to gender alone, the article asks lawmakers to consider other structural factors that drive violence including but not limited to the nuclear family structure, the role of religious education and its teaching about marriage, the concept of love as equating to sacrifice, and the influence of alcoholism. In addition, the authors criticize the law for portraying punishment as a solution to resolve problems and conflicts when "experience demonstrates that more punishment does not imply less crime nor greater protection for victims" (Pineda, 2006).

The 2006 article was one of the most organized and visible collective critiques to Law 1/2004. Other anti-carceral critiques of Law 1/2004 have come from smaller activist and professional blocs- two examples being The Network of Latin American and Caribbean Women ${ }^{19}$ (Latina Network) and The General Council of Social Work. While both organizations do not explicitly identify as anti-carceral feminists or prison abolitionists, their demands question the ability of the justice system to properly attend to the needs of all gender violence survivors. The Latina Network and The General Council of Social Work may be more marginalized in major debates, but their ideas offer a ripple of resistance to the commonsensical belief that gender violence justice correlates to the severity of a prison sentence. Rather than reforming a structurally

\footnotetext{
${ }^{19}$ Member organizations consist of: Asociación Casa de Colombia en España. Asociación Estudios y Cooperación para el Desarrollo. Asociación de Investigación y Especialización Sobre Temas Iberoamericanos. Asociación de Mujeres Latinoamericanas AMALGAMA. Asociación de Mujeres Inmigrantes en Castellón. Asociación de Mujeres Supervivientes de Violencias de Género. Asociación Genera Enlaces. Asociación Por Ti Mujer. Asociación Malen Etxea. Asociación Mujeres Pálante. Asociación Servicio Doméstico Activo. Colectivo Brujitas Migrantes. Colectivo Red de Hondureñas Migradas. Red de Apoyo a la Mujer Inmigrante victima de VG. Red de Mujeres Latinoamericanas y del Caribe. Asociación América-España, Solidaridad y Cooperación. Asociación de Chilenos y Chilenas en España. Associació Intercultural diálogos de dona. Asociación de Mexicanas en Madrid. Red Internacional de Abogados EUREKA. Save a Girl, Save a Generation. Sindillar/Sindihogar, Sindicato de trabajadoras del hogar y de cuidado
} 
patriarchal and racist system, both organizations recommend divesting from punitive policies and reinvesting in rehabilitative programs.

Since 2010, The Latina Network has organized actions and published research on how gender violence affects migrant women. In a more recent 2020 publication, the collective received funding from the Spanish government to conduct a research project alongside the Asociación de Investigación y Especialización Sobre Temas Iberoamericanos ("Association for Research and Specialization on Hispanic Issues") aimed at analyzing the reactions from migrant women in respect to Law 1/2004. The document harks on the need to walk back from criminalization demands and invest in transformational social justice programs. The authors highlight how migrant women are disproportionately less likely to present and follow through with judicial proceedings due to fears of retaliatory violence, biased treatment from the justice system and/or deportation (Asociación de Investigación y Especialización Sobre Temas Iberoamericanos, 2020). Moreover, they demand Law $1 / 2004$ consider a reparative and preventive approach, rather than the existing criminalizing and revictimizing approach in the penal code, to female genital mutilation (FGM) and sex work. The document addresses the unique vulnerabilities migrant women, who are more likely to experience FGM and participate in sex work, confront while interfacing with a justice system not catered to their often racialized and vulnerable legal position (p. 29).

Social workers represent another critical voice against penal gender violence interventions. The General Council of Social Work is a national network of over 40 thousand social work professionals working all over Spain that sets the best practices standards for how social workers can best serve the clients that interact with public supports. According to a statement released in 2018, the network insists that fourteen years have passed since the implementation of Law $1 / 2004$, and victims still do not trust the justice system enough to protect them against situations of violence. The Council specifically criticizes how survivors can only enter through the justice system to be recognized as a gender violence survivor and gain access to public assistance. They call on lawmakers to abolish any statutes that oblige survivors to report and allow more social service organizations to accredit someone as a gender violence victim (Consejo General de Trabajo, 2018). 
The carceral rhetoric of institutional feminists materialized into Law 1/2004's exclusionary frameworks and punitive responses. The consequential rebounding political success of Law 1/2004 further emboldened institutional feminists to prioritize law enforcement in their subsequent calls for action on gender violence. Scattered groups of activists, scholars, and professionals, such as migrant women and social workers have resisted the carceral logics and tactics embedded into the legislation, but their responses remain marginalized alongside more noisy calls for criminalization.

\section{"The Yes Means Yes Law": the next frontier}

The Ministry of Equality has championed The Yes Means Yes Law as one of the most progressive laws for women in Spain right now. It is meant to be a feminist victory and hallmark human rights legislation for women and girls. This chapter explores whether the Yes Means Yes Law can deliver on its promises of guaranteeing sexual freedom and revolutionizing patriarchal sexual cultures. I take up the same structure and methodological tools as the last chapter: I deliver a brief context of immediate social-political conditions and then analyze the terms "victim" and "justice" according to a genealogical and critical discourse analysis.

\section{Context}

The socio-political conditions surrounding The Yes Means Yes Law require more explanation than the previous chapter given the large gap between the two pieces of legislation. The goal of this section is not to summarize the entirety of feminist debates and focusing events in the past two decades but rather spotlight central developments in the political, judicial, legislative and social spheres that ripen the terrain for a sexual violence bill like The Yes Means Yes Law.

Political- PSOE, Podemos, PP and VOX: The Minister of Equality, Irene Montero, with the support of Spain's socialist parties Podemos and Partido Socialista Obrero Espanol (PSOE), introduced the first draft of the Organic Law for the Guarantee of Sexual Freedom in March 
$2020 .^{20}$ The Yes Means Yes Law still has to pass through Congress in order to officially become codified into law (Santana, 2021), but Montero has promised the public that it will be debated in Congress by the end of Summer 2021 (EuropaPress, 2021a). The bill faces an uphill battle in Congress against members of the right-wing parties, Partido Popular (PP) and VOX, and their allies. The General Council of the Judiciary (CGJP) submitted a unanimous report to Congress declining to support the bill because it contradicts the presumption of innocence before proven guilty and dissolves sexual abuse as a crime (leaving only sexual aggression which encompasses a wide range of circumstances and penalties). While Congress will take the CGJP's opinion into consideration, the law may still enter and pass through Congress without the CGJP's support (Santana, 2021). Before Congress debates and votes on the bill, the Council of the State needs to approve it and provide their recommendations. Even though The Yes Means Yes Law criminalizes sex work and increases sentences, it is far from likely to pass with the same level of rebounding support as Law 1/2004 unless it shifts some of its central clauses.

The assumption of PSOE and Pedro Sánchez into power has given feminist collectives a window of opportunity to pass comprehensive sexual violence legislation. Coming off the heels of a Mariano Rajoy presidency stained by corruption scandals and the financial crisis (PP), the public began to seek a major political change. The popularity of Rajoy, who had won a landslide victory in 2011 with promises to recuperate the economy, plummeted after instituting austerity measures on the working class while bailing out the entire banking sector. With unemployment at 27 percent in 2012 , a series of anti-austerity protests sprouted across the country that later became known as the $15-\mathrm{M}$ or Indignados movement. Nearly 6.5 to 8 million people participated nationwide leading Pablo Iglesias to form the socialist party Podemos in homage to the movement (El País, 2016). Congress eventually ousted Rajoy for being "unfit for office" after various financial scandals came to light. Podemos, PSOE and Ciudadanos (a leftist-centrist party) formed the United Left alliance to win back the government in 2018 making it the first time in the history of Spanish democracy that there is a multi-party administration (BBC, 2018).

2018 also brought strong oppositional representation from the far-right for the first time since the death of Franco in 1975. The VOX party, an ultra-conservative nationalist group, gained 24 seats

20 I evaluate the second and most recent draft of the bill introduced in October 2020. 
in Congress and shocked many in the public who thought that the country was immune to the far right because of memories of the dictatorship. In 2019, VOX found even more footing when they reached 52 seats- more than a 100 percent increase in representation in one year. VOX grew out of the discontentment of several members of PP who thought the party was drifting too far to the center. The group aims to roll back Law 1/2004 and bar any other gender violence legislation from passing, including The Yes Means Yes Law, because it allegedly discriminates against men. Other key issues at the center of VOX's platform are their strong opposition to undocumented immigration (specifically those arriving on the Southern shores of Spain from Africa), gay marriage, and Catalonian autonomy. The party has joined the ranks of many other extreme right groups in Europe and the U.S. who incite cultural wars against Islam, feminists, migrants and LGBTQ+ people in the name of "making Spain great again" (Hedgecoe, 2019).

Judicial- La Manada Verdict: The verdict of the 2018 La Manada (The Wolfpack ${ }^{21}$ ) case and its subsequent protests were the main focusing events that prompted The Yes Means Yes Law. During the 2016 Running of the Bulls Festival in Pamplona, five men gang raped an 18-year-old woman. The perpetrators recorded themselves raping the woman while she remained motionless. The Superior Court of Navarra found the five men guilty for the lesser charge of sexual abuse but not rape because "the men did not use force or intimidation" and "the woman did not resist". The prosecution argued that the survivor did not fight because she was "paralyzed in fear for her life" (Saiz, 2020). 1,800 Spanish psychologists and psychiatrists issued a statement in support of the survivor mentioning that it is completely normal for a victim to remain still in a moment of shock and trauma. The experts added that perpetrators rather than victims should be the focus of investigation and victims' post-trauma recovery should not be scrutinized as evidence of consent to violation. The latter comment arose from the discovery that the defense hired a private investigator to follow the survivor in order to show that she is "living a normal, trauma-free life". Many argued that the defense's tactics were classic examples of revictimization (Álvarez, 2018).

21 The case became known as The Wolfpack after the WhatsApp group that the men used to discuss their sexual exploits (Saiz, 2020). 
Once the verdict went public, nationwide demonstrations erupted across Spain with feminists decrying the judges for blaming the survivor and for the levity of the sentence. The Spanish Supreme Court eventually appealed the case and shifted the verdict from sexual abuse to sexual aggression and increased their sentences from nine to fifteen years in prison. The Court in the Province of Córdoba sentenced the perpetrators to another year and four months in prison after more video footage emerged of the men assaulting another woman while she was unconscious only two months before the Manada Case. The Court ruled that it was sexual abuse rather than rape because the woman was unconscious and could not say no. A spokesperson for the Clara Campoamor Association (a group serving survivors of gender violence) resounded that the sexual abuse conviction was too light: "It means carte blanche for gang abuse and assault" (Saiz, 2020).

The Manada Case sparked international attention from the EU Parliament and the United Nations. The EU Commission and Council added statements about Spain's lack of accordance with international sexual violence standards to the Parliament's debate agenda. Additionally, Purna Sen, the Executive Coordinator at UN Women, commented on the case in a statement about global sexual violence. She wrote, "The light sentencing of 'the wolf pack' attackers in Spain diminishes the severity of the violation and undermines clear obligations to uphold the rights of women. Justice must be known by women" (Álvarez, 2018).

Legislative- The Istanbul Convention and The State Pact: Since Law 1/2004's limited application to affective relationships, feminists have pushed for more comprehensive legislation for sexual violence. The 2011 Council of Europe Istanbul Convention on Preventing and Combating Violence Against Women and Domestic Violence has further pressured Spain to adopt sexual violence standards in line with international law. Spain signed the treaty at its onset in 2011 and ratified it in 2014. As of June 2021, 46 member countries and the European Union signed the treaty and 35 countries implemented it (Council of Europe, 2021). During the Manada case, prosecutors and demonstrators repeatedly referenced the state's violation of the Istanbul Convention, and its definition of rape and consent. The Convention differentiates sexual assault and rape on the basis on penetration of a bodily part or object (art. 36.1). It asserts that all acts of sexual violence, including sexual assault and rape, depend on the consent of the victim. 
Wherein, "consent must be given voluntarily as the result of the person's free will assessed in the context of the surrounding circumstances" (art. 36.2). This directly conflicts with the Spanish Penal Code's definition of rape which does not depend on the victim's consent but rather if the perpetrator forces the victim into an act using violence and intimidation (art. 177.1). This places the burden of proof on the victim to show that the defendant forced them to participate in an act. On the other hand, the Istanbul Convention shifts the burden of proof to the perpetrator to prove that the victim consented willingly and unequivocally. Victoria Rossel, Government Delegate of Gender Violence, defended the reframing of consent in The Yes Means Yes Law by reminding members of the judiciary that compliance with the Istanbul Convention demands such a revision (Guede \& López-Macías, 2021).

The 2017 State Pact Against Gender Violence became another advocacy tool for supporters of The Yes Means Yes Law. Congress passed this document in 2017 after feminist groups and leftist parties began to push for more public policy devoted to eradicating gender violence. Sponsors of the Pact aimed to "recuperate the spirit of consensus embodied in Organic Law 1/2004" and "reach an agreement between all political forces and institutions in the country" (Ministerio de Igualdad, 2017, p. 3). The Pact would supposedly make positive steps toward compliance with the Istanbul Convention and would bind all political parties and institutions in committing to long-term gender violence policy. The Pact represents a willingness of all political parties of opposing ideals to come together and agree on long-term state policy goals without the future interference of whatever party is in power. While State Pacts just need a parliamentary majority to pass, the State Pact Against Gender Violence passed unanimously (reminiscent of the passing of Law 1/2004). It put into place a Government Delegation for Gender Violence, of which Victoria Rossel would eventually lead and be responsible for coordinating and promoting the adoption of measures. It also pledged over one billion euros for the next five years for local entities, autonomous communities and the state budget (Ministerio de Igualdad, 2017, p. 5).

Most relevant to The Yes Means Yes Law, the Pact widens the concept of gender violence to all those included in the Istanbul Convention such as, rape, sex trafficking, sexual harassment, forced abortions and sterilization, forced marriages and female genital mutilation (art. 2.6). Moreover, it calls for the creation of a comprehensive and gender-sensitive law addressing 
sexual violence (art. 2.6). The Istanbul Convention and the State Pact are partly symbolic because they do not have any legal repercussions. However, they act as best practice guides as well as make formal promises to the international and domestic community that Spain will meet certain human rights standards. Members of Podemos and PSOE, including Montero, have emphasized the violation of the Istanbul Convention and the State Pact to send a message that the country is falling behind international human rights benchmarks and to inspire demands for accountability (EuropaPress, 2021b).

Social- COVID-19 and Gender Violence: Because COVID-19 exacerbated incidences of gender violence, The Yes Means Yes Law further became a relevant theme on the political agenda. During the lockdown, service professionals warned the public that victims were more vulnerable to abuse because physical restrictions and social isolation posed more obstacles for seeking services and reporting (Bodelón-González, 2020, p. 120). Violence became more lethal since restrictions loosened in May 2021 with 12 femicides in one month. This is more than half of the 20 femicides that have occurred in the entire year of 2021 so far (Méndez, 2021). The cases of vicarious violence against Anna and Olivia Zimmerman ${ }^{22}$ and the femicide of Rocío-Caíz ${ }^{23}$ grasped the public's attention and caused widespread demonstrations in Tenerife, Sevilla, Granada, Madrid, Barcelona, A Coruña, San Sebastián, Málaga, Valencia and Valladolid (Cadena Ser, 2021). The sudden increase of vicarious violence and femicides has sounded alarms about the state of gender violence as the country increasingly disseminates vaccines and turns a corner of hope for a de-escalation of the pandemic.

The resulting protests nationwide suggest a need for state accountability, especially from the criminal justice system. Protestors and experts overwhelmingly expressed their frustration with how the judicial system intervenes in gender violence and especially vicarious violence and femicides. In la Puerta del Sol, a woman working for Nosotras Mismas stated, "We are very angry because the judicial power keeps not believing women when they report that [their partners and ex-partners) maltreat their children and can kill them" (Álvarez, 2021). The forensic

\footnotetext{
22 The ex-partner of Zimmerman murdered her two daughters as a form of vicarious violence on the island of Tenerife (Vega, 2021).

${ }^{23}$ The 23-year-old ex-partner and father to their four-month old child murdered 17-year-old Rocio Caiz in Sevilla (Moreno, 2021).
} 
scientist, who formerly served as Government Ex-Delegate against Gender Violence, Miguel Lorente, commented "Besides working on prevention, these cases [vicarious violence and femicides] leave us with little capacity to act. There are people who do not fear the law nor the consequences. They just remove themselves from the equation"24 (Álvarez, 2021). Amparo Díaz, a gender violence lawyer added, "The judicial system is not improving in the area, there are women who fear reporting because they think the consequences are worse than their situation. They fear the judicial system and that is very serious" (Álvarez, 2021). Protestors' discontent with the capacity of the judicial system to properly attend to gender violence suggests a pressure for lawmakers to pass a Yes Means Yes Law that includes restorative measures.

In conclusion, this background sheds light on the recent political, judicial, legislative and social conditions that shape and are shaped by The Yes Means Yes Law. I assess the temperature on gender violence demands by gathering recent important events that have triggered protest and political demands. The responses and actions of political actors, nationally and internationally, construe their prioritization of racialized and trans people and sex workers in recent gender violence policies and The Yes Means Yes Law.

\section{Analysis: victim and justice}

In the previous chapter, I analyzed the terms "victim" and "justice" to unveil the carceral discourses embedded in Law 1/2004. Here, I use the same methodology to locate the carceral discourses found in The Yes Means Yes Law. I again sift through the Law's goals, reasonings and measures to answer how the law defines the subject of harm and how to amend that harm. These findings provide a foundation for drawing the links and disconnections between the two pieces of legislation.

Victim: According to The Yes Means Yes, a victim of sexual violence is someone who experiences "non-consensual acts of a sexual nature or those that limit the free development of

\footnotetext{
24 Lorente refers to how many femicides end in murder-suicide where fear of imprisonment has little to no effect. Femicides and vicarious violence are often the iceberg of abuse that draw the most attention because of their severity and horror, but a lot of instability factors precede lethal abuse where survivors can be offered more resources.
} 
sexual life in whatever public or private environment" (Motivation Statement, I). Like in the description of gender violence in Law 1/2004, there is an emphasis on the public and structural nature of sexual violence to draw attention to the great scale of the issue and the state's role in resolving it. The Law lists a range of sexual violences including "sexual aggression, sexual harassment, exploitative prostitution, non-consensual pornography, sexual extorsion, female genital mutilation, forced matrimony, forced abortion, stalking with a sexual connotation and sexual exploitation" (Motivation Statement, I). In this way, The Yes Means Yes Law shows a commitment to defining sexual violence beyond the private, partner realm.

The use of the terminology "non-consensual" in the prior definitions of sexual violence points to a significant shift in how lawmakers intend to describe sexual violence. The Law specifically draws on a framework, now known as its crowning achievement and the reason for its nickname, called affirmative consent. The bill cites that it adopts the affirmative consent framework presented in the Istanbul Convention (Motivation Statement, III). According to Convention, consent, instead of the use of intimidation and violence, is the ultimate factor which determines whether an act is rape. The text states that consent only exists when someone "freely and unequivocally expresses her willingness to participate in the act" (Council of Europe, 2011, art. 36). This revision removes sexual abuse- a crime that the judiciary commonly used to sentence those who raped or sexual assaulted someone without the alleged use of force and violence. If Congress passes The Yes Means Yes Law, all penetration without consent will be considered rape, and any other non-penetrative sexual act without consent will be considered sexual aggression. Penetrative acts consist of skin-to-skin contact, corporal penetration or object penetration with vaginal, anal and oral cavities (art. 178).

Beyond the harms that qualify someone as victim, the bill imposes limitations on the demographic characteristics of who experiences sexual violence. The text consistently uses the female-gendered language to describe victims because violence "affects in specific and disproportionate ways women and girls, but also boys" (Motivation Statement, I). It mentions that young boys can be victims of gender violence, but older men cannot. It implies that adult, cis men are the perpetrators, and women and girls (and sometimes boys) are victims. It reasons women and girls are the overwhelming majority of victims because of "established gender roles 
in a patriarchal society, that sustain discrimination against women and penalize, through violent forms, expressions of their liberty" (Motivation Statement, I). In other words, patriarchal gender roles are the primary driving discriminatory force that causes gender violence against women and girls.

The Motivation Statement uses the concept of intersectionality to further explicate how victimization occurs. It states that one's gender experience is uniquely determined by their other overlapping identities, and the nature and impact of gender violence vary from victim to victim:

This Organic Law adopts intersectionality as a basic concept to describe the State's obligations against discrimination and its impact. Discrimination motivated by gender is linked indivisibly to other discrimination factors such as disability, racial and ethnic origin, sexual orientation, gender identity, social class, access to documentation, national origin, religion, conviction or opinions or civil status. (I)

The Law takes this approach because they recognize that "other factors determine that not all victims have the same opportunities to live without violence and to obtain an adequate response in their search for support, protection and justice" (Motivation Statement, I). It implies that these "discrimination factors" make one more likely to experience violence and less likely to access services. The Statement then promises to attend to these disparities by "adapting to their diverse necessities and respecting and strengthening their autonomy, with special attention to victims who are minors and have a disability" (III). The section specifically draws special attention to minors and people with disabilities, but it does not mention any specific programming for these populations. It only vaguely mentions the "right to information" for people with disabilities and non-Spanish speakers and the creation of intersectional educational curricula for minors and service professionals (art. 18). The Yes Means Yes Law does not take any further specific measures to improve services for the marginalized populations it mentions.

Affirmative consent and weak intersectional interventions coincide with larger legal progressions globally and in Spain. Affirmative consent has become an international standard for "progressive" sexual violence legislation and a popular rallying cry across the world for rape activists trying to rectify the common legal defense that the absence of no, force, or violence means yes. As of 2020, 12 other European countries have adopted affirmative consent laws: 
Belgium, Croatia, Cyprus, Denmark, Germany, Greece, Iceland, Ireland, Luxembourg, Malta, Sweden and the UK (Amnesty International, 2020a). The US has also implemented secured affirmative consent laws in four states ${ }^{25}$ and 16 states are currently considering them. The Council of Europe (2011) and the United Nations (2010) recommend affirmative consent as a requirement for meeting global human rights obligations for women, girls and children. Both entities claim that this conception of consent will improve sexual culture by incentivizing men to ensure women give consent before they initiate sexual contact. Consent will give women the freedom to decide the trajectory of their sexual engagements and help produce a world where women enjoy sex on equal basis with men (Halley, 2016, p. 258).

In terms of intersectionality, institutional feminism continues to follow the neoliberal ethic of queer, trans, and migrant issues as separate and unrelated issues to feminism. Parallel LGBT and immigration legislation, simultaneously proposed by the left, displays how violence against queer, trans and migration populations is not meaningfully considered in gender violence discussions. Irene Montero and Podemos have championed the Trans Law and The Yes Means Yes Law claiming that the laws will respectively ensure trans equality and freedom from sexual violence. However, The Yes Means Yes Law criminalizes sex work and excludes sex workers, who are disproportionately trans, from sexual violence protections. This conflicts with the Trans Law's goal to promote the inclusion of trans people in the labor market. In addition, the Trans Law only attends to violence against queer and trans people through anti-discrimination hate crime policy, but it does not attest to how they can be victims of interpersonal and gendered violence. The Trans Law solely addresses gender violence while demarcating how gender identity cannot be used to face lesser criminal sentences (20 Minutos, 2021). This was a main point of critique from PSOE and other right-wing parties who believed that adopting more fluid understandings of gender will mean rejecting violence instigated by gender inequality and threatening important advancements made for women through Law 1/2004 (Álvarez, 2021). The introduction of these two conflicting laws at the same time demonstrates the neoliberal legal pattern of the Spanish left.

${ }^{25}$ New York, Illinois, Connecticut and Colorado 
Similarly, Spanish immigration legislation does not address the unique experiences of migrant survivors of gender violence beyond their legal documentation status. Since 2000, all immigrant women suffering from gender violence have been eligible for legal residency and working rights if they file a criminal complaint against their perpetrator. Law 4/2000 stipulates that the woman will face criminal charges, including deportation, if the penal process does not grant them victim status. Meanwhile, subsequent immigration policy has growingly infringed on the rights of migrants to access humanitarian aid, residency, and health care. The Organic Law 14/2003, a reform of $4 / 2000$, reinforced border controls, sped up deportation procedures, and toughened police registration checks. More recent revisions (Organic Law 2/2009, Organic Law 10/2011, and Royal Decree 16/2012) have only tightened punitive controls in response to demands from both the left and right for a crackdown on the greater number of migrants arriving to Spanish shores from Northern Africa. The deaths of nearly 22 thousand migrants attempting to cross the Mediterranean Sea, not including those missing (Missing Migrants Project, 2021), has jolted the topic into the center of public debate, leading to nationwide protests and strife within the left (Martín M., 2020). Whereas PSOE has historically sided with the right for stricter police controls, Podemos has advocated for more humanitarian aid and access to documentation (Martín M., 2020). The historical anti-immigration stance of PSOE provides greater context for why The Yes Means Yes law lacks a more substantial intersectional approach to victimhood.

The Law's subscription to affirmative consent and its conservative perspective of victimhood spark several concerns. Several scholars agree (Gruber, 2020; Halley, 2016; Garaizabal et.al., 2020) that consent is key to determining if sex is indeed rape or assault, but say the framing, and, particularly, the simplification of consent infantilizes women and marks them as inherently vulnerable. It divides the world into "a mere two sexes" and reduces diverse sexualities into "a model of (heterosexual) male domination and female subordination-all of these are strong markers of conservative social values" (Halley, 2016, p. 276). The fact that women can only assert "yes" and not both parties, positions women as gatekeepers of their "sacred sexuality"an idea that is commonly associated with conservative religious views rather than sexual empowerment. Assuming all sexual acts are crimes without an "explicit yes" (a reality that most ordinary sex does not live up to), sex is posed as always dangerous. It does not give women the 
power to elaborate on their own terms what are their sexual limits and, instead, creates a paternal protectionary power to do so (Halley, 2016, p. 267).

While The Yes Means Yes Law offers a more fleshed-out definition of intersectionality, it still prioritizes white, cis-heterosexual victimhood like in Law 1/2004. It limits victimization to women and children but excludes, gender-queer and queer individuals, who disproportionally experience violence at even greater rates than cis women (Turrell, 2000; Messinger, 2011; Kelley et.al., 2012; Clifton, 2021). I mention how gendered crimes against trans, queer and migrant people are only addressed through anti-discrimination hate crime policy such as the Trans Law and migrant laws among others. The classification of these violences as discrete fails to attend to the specificities of intersecting and widespread administrative harms. In the Theoretical Praxis, I take from Dean Spade (2013) who explains how population-level systems manufacture harm and risk through systemic racist, transphobic and xenophobic policies. Without a more complex legal approach to differentiated victimhood, the Yes Means Yes Law institutes measures that best serve the normative victim. ${ }^{26}$ As the following analysis evaluates, the Law's loyalty to punitive justice jeopardizes the well-being of marginalized communities.

Justice: Like Law 1/2004, The Yes Means Yes Law consistently emphasizes the need for a "coordinated" and "comprehensive" response to amend sexual violence harm. It implements prevention, detection, training and assistance mechanisms across health, educational, social, judicial and labor systems. While explicitly defining justice, the Law states that one of its two important objectives at the level of justice is to "drastically reduce the sources of revictimization for boys and girls" (Motivation Statement, II). The bill argues that it can reduce victimization through the design of accessible and intersectional services that involve a "coordinated participation... of professionals that intervene in the path to care and justice" (Motivation Statement, II). The body of the bill mainly refers to revictimization when discussing the victim's experience in the criminal justice and forensic systems (art. 47). This brings us to the second objective of justice which is to guarantee the "safe and secure testimony to increase the possibility of satisfactorily concluding the investigation of facts, which are difficult to prove"

\footnotetext{
${ }^{26}$ Just like Law 1/2004, there is a clause that dictates victims must register with the criminal justice system to gain accreditation of victim-status and access to its associated rights (Motivation Statement, II).
} 
(Motivation Statement, II). In the end, both objectives target the criminal justice system: objective one wants to reduce revictimization in the criminal and forensic system, and objective two aims to improve witness testimony and increase convictions.

The bill promises to hold those who violate affirmative consent in any act of a sexual nature accountable through punishment. Like 1/2004, the bill increases sentences and tightens prosecutorial procedures and funnels more money into the criminal justice system. The most well-known shift is the removal sexual abuse, previously accompanied by one to three years in prison, for sexual aggression worthy of one to four years in prison (art. 178). Sexual harassment sentences increase from three to seven months of prison to six to twelve months with the addition of a termination of employment. Additionally, Article 180 introduces several new aggravating factors that increase prison time for sexual aggression to two to six years and the sentence for rape to seven to 10 to 12 years. An accumulation of two aggravating factors could mean nine to 15 years in prison for rape. Without the addition of aggravating factor, the sentence for rape technically decreases from four to twelve years to four to ten years of prison. However, the new rape definition has the new consent framework and has lower standards for burden of proof. The text also introduces street harassment as a new crime punishable by house arrest, community service or fines. Finally, the bill designates funds for specialized special violence units, investing more money into penal approaches and divesting potential funds toward non-carceral solutions (art. 42-45).

The most recent version of The Yes Means Yes Law bill published in October 2020 incorporates new penal sanctions against sex work. Broadly speaking, Spain does not regulate nor complete bar sex work, but The Yes Means Yes Law aims to corner a specific sector of the market dedicated to "pimping". To do so, the bill sanctions anyone who is in a "relationship of dependency or subordination" performing sex work, even if they consent to such labor. Those who commit such an offense will face two to four years in prison and six to eighteen months of fines (art. 187bis). Next, the text reinstates the terceria locativa ("third party location") provision in the Penal Code. Terceria locativa criminalizes anyone who "for profit and in a habitual manner uses a property, premises or establishment, open or not to the public, to favor the exploitative prostitution of another person, even with their consent" (art. 187bis). The penalty for such an 
offense is one to three years of prison time and fines from six to eighteen months (art. 187bis). It is unclear how the law enforcement officials will determine whether someone is in a dependent or subordinate position or what is a "third party location". However, sex workers have signaled that it could be used to penalize sex workers who live together (Aula Virtual Fundación de los Comunes, 2021).

The punitive character of Yes Means Yes fits into a greater pattern of punitive pandemic politics. In response to COVID-19, the Spanish state has privileged the police more than any other public entity and divested from civilian emergency teams, firefighters and public health community organizations (Bodelón-González, 2020, p. 98). With the strictest restrictions and sanctions in Europe, the police issued over a million fines and arrested 8,500 people for disobeying lockdown restrictions from March 15th to April $3^{\text {rd }}$, 2020 (Amnesty International, 2020b). According to an Amnesty International (2020b) report, Spain received 70 cases of discrimination and police abuse between March 15th, 2020, and May 2nd, 2020. The United Nations further denounced Spain for its treatment of people of afro-descent. According to a report by the Working Group of Experts on People of African Descent (2020), 70 percent of incarcerated people of afro descent report that they experienced abuse and brutality by the Spanish police.

Regarding punitive gender violence politics, the government published a contingency plan aimed at "victims of trafficking, sexual exploitation and at women in contexts of prostitution" in April 2020. The plan promises to improve screening and quality social services as well as ensure the right to the minimum wage and housing alternatives for those experiencing exploitation (Ministerio de Igualdad, 2020). However, the plan does not differentiate between victims of exploitation and sex workers and frames sex workers as always already victims of gender violence. In conflict with the Istanbul Convention, the plan delegates the police as the body who identifies and intervenes in situations of exploitation which ultimately includes anyone engaging in sex work. As a result, the plan reinstates further jurisprudence for the criminalization of sex work (Bodelón-González, 2020, p. 118).

Several other EU and UN resolutions have supported the criminalization of sex work. In 2014, the European Parliament passed a resolution on sexual exploitation and prostitution and its 
impact of gender inequality which legislators designed to bring homogeneity to legislation ${ }^{27}$ that varies from state to state. The resolution reads:

Prostitution and forced prostitution are gendered phenomena with a global dimension involving around 40-42 million people worldwide, with the vast majority of prostituted persons being women and under-age females, and almost all buyers being men, it is therefore both a cause and a consequence of gender inequality. (A)

Through this resolution, the EU clarified its stance that sex work is sexual violence and sex workers are victims. The resolution is non-compulsory, but EU deputies have expressed their support for a Nordic Model that criminalizes pimps and offers support for sex workers to leave "dangerous" situations. It deems the consent of a sex worker irrelevant because one cannot accept conditions of exploitation. The Yes Means Yes quietly inches toward the Nordic Model by defining sexual exploitation as "the prostitution of another person even with their consent...when there is exploitation of a relationship of dependence or subordination" (art. 187.2).

The EU has also ratified the 2000 UN Palermo Protocol to Prevent, Suppress and Punish Trafficking in Persons Especially Women and Children which adopts abolitionist standards. The Protocol seeks to eradicate sex trafficking including "the exploitation of the prostitution of others or other forms of sexual exploitation, forced labour or services, slavery or practices similar to slavery, servitude or the removal of organs" (art. 3). In a subsequent report, one of the leading coordinators clarified the intentions of the Protocol to endorse the Nordic model when she stated, "organized crime, human trafficking, extremely violent and corruption flourish in the shadow of prostitution" (European Parliament, 2014). It equates sex work with sex trafficking because it rests on "the abuse of power or of a position of vulnerability or of the giving or receiving of payments or benefits to achieve the consent of a person having control over another person". Spain ratified and proposed to implement the Palermo Protocol through La Ley Integral Contra la Trata (“The Comprehensive Law Against Trafficking”). This proposed law would view sex work, legalized or not, as controlled by organized crime and pervaded by sex trafficking.

27 The Nordic model (criminalization of clients and pimps, not workers); German model (legal and regulated); Spanish model (legalized and uncontrolled); and Eastern European model (criminalization of clients and workers). 
Therefore, it contends that all sex workers, forced or not, are victims of sexual violence, including sex trafficking, and need protection mechanisms (La Moncloa, 2021).

From a national standpoint, the feminist movement held diverse debates about sex work during the 1970s. They debated issues such as whether to eradicate prostitution, free sex workers incarcerated during Franco era and grant sex worker protection rights (Gil, 2011, p. 59). By the 1980s, sex work became a much more poignant issue between political parties. One activist recalls how institutional feminists operating within PSOE caused "real damage...and dragged many women under the bus" with their new criminalization agendas (p. 108). This philosophy remains true in PSOE today. According to PSOE's website, "PSOE is firmly and decisively committed to its abolition...Prostitution represents a flagrant violation of the human rights of the women and children who suffer it on a daily basis" (Martínez-Riber, 2020). Still, the policies of institutional feminists have been met with harsh resistance from trans, migrant and sex worker collectives. In 1991, various of these latter groups published a manifesto addressing segregation and criminalization that remains relevant to many of the measures taken in The Yes Means Yes Law (Gil, 2011, p. 168).

To connect this wave of punitivism to current debates, Halley (2016) points to how affirmative consent traditionally supports criminalization. At face-value, affirmative consent sounds desirable and progressive; all sex should require agreement to participate. The tricky aspect of The Yes Means Yes Law is its commitment to liberal values and promise that it can transform sexual mores through law and punishment. Halley (2016) poignantly explains that affirmative consent values are inextricably tied to a carceral project whose reliance on punishment for social control is more conservative than emancipatory:

Grounding women's emancipation, sexual and otherwise, on such a sweeping use of criminal punishment and civil incapacitation... has led feminist reformers to take several stances typically thought to be hallmarks of social conservatism. They are seeking social control through punitive and repressive deployments of state power. They are criminalizing as a first rather than a last resort to achieving social change. (p. 264)

This critique does not minimize the aspiration for women to have consensual and enjoyable sex, but it does question whether legal reform and specifically swifter convictions and higher prison 
sentences are the best avenue to change patriarchal cultures around sex. Halley (2016) warns how increased punishment will land disproportionately on groups thought to be sexually "dangerous", such as men of color, poor men and gender nonconforming people (p. 278). "Criminalizing as a first rather than last resort" enforces more social control and repression than social change (p. 264).

Further worrying is how affirmative scale seeks to scale up criminalization, including of sex work. To find this agenda, one must go back to the roots of affirmative feminism. Affirmative consent grew out of a 1980s strain of legal feminism known as dominance feminism. The leading thinker on dominance feminism, Catherine McKinnon, was an anti-rape activist who argued that sexual emancipation will occur when women have sex only when they desire or want it. McKinnon posits that placing legal sanctions on men who engage in a sexual act with women who did not desire or want it will bring women closer to such a world. Dominance feminists aim to widen criminalization by sanctioning consent beyond the nonconsensual (non-agreed) to the unwanted (undesired). From their view, undesired sex includes sex work because sex workers cannot freely choose and enjoy sex for money. If dominance feminists had their way, affirmative consent would also sanction ordinary or transactional sex (otherwise known as sex work) that women may have agreed to but may have not been enthusiastic about or later regretted (p. 264). Sex workers warn how that such abolitionist framings of consent do not give sex workers the opportunity to consent to an act (Aula Virtual Fundación de los Comunes, 2021). Encarna Bodelón-González (2020) writes, "assimilating sex workers with gender violence victims denies sex workers of their political subjectivity" (p. 118). New laws in the era of the pandemic, such as the contingency plan and the Yes Means Yes Law, add further stress to sex workers who are experiencing increased economic precarity from loss of work and are now being further policed. Designating the police has the primary entity that detects and intervenes puts people who really are suffering from trafficking, exploitation or sexual violence at risk because the abolitionist organizations who provide information to the police have less access to many sex workers collectives (Bodelón-González, 2020, p. 199).

All in all, The Yes Means Yes Law strips sex workers of their political and economic agency and simplifies the complexities of sexual victimization versus labor exploitation. Many socially and 
economically marginalized people engage in sex work to survive precarity driven by capitalism. Nearly 91 percent of sex workers in Spain are trans and migrants from Eastern Europe, Africa and South America (Cruz, 2018). Neo-abolitionism erases these structural influences of capitalism, racism, xenophobia and transphobia on access to safe working conditions and, alternatively, pins it all on patriarchy. This reduction of intersectional oppression supports an ideal victim narrative that depends on the paternal rescue of women, especially from men of color. Neoliberal anti-immigration discourse fits neatly alongside abolitionism as it blames migrant men for gender related crimes in order to garner support for xenophobic policies (Farris, 2017). Despite intentions to liberate women from sexual oppression, The Yes Means Yes Law's abolitionist reframing promotes policies that jeopardize the well-being of women, especially those who are migrants and trans.

\section{Resistances to The Yes Means Yes Law}

Sex workers form part of the most visible resistance to The Yes Means Yes Law. Four major sex work organizations, Prostitutas de Sevilla (CPS), Las Putas Libertarias del Raval (Barcelona), La Sección de Trabajadoras Sexuales de la Intersindical Alternativa de Catalunya (IAC), and Agrupación Feminista de Trabajadoras del Sexo (AFEMTRAS) wrote a collective letter to the United Nations Rapporteur of Health Care Rights stating their concerns about their safety (Albarrán-Méndez, 2021). Then in an even larger collective effort, 115 feminist organizations signed a manifesto entitled "Listening to legislate" (Escuchar para legislar) in March 2021. The groups harshly criticized the new penal measures and demanded their removal. Their main concern is the terceria locativa because it would criminalize sex workers who share property. They claim how the bill denies the sexual autonomy of sex workers and their capacity to consent and express their concern that lawmakers did not consult any sex workers while making of the bill. The groups believe The Yes Means Yes Law will only increase stigmatization and the precarity of sex workers.

In an online conference discussing The Yes Means Yes Law, sex workers from Prostitutas de

Sevilla, Agrupación Feminista de Trabajadoras del Sexo (AFEMTRAS) and Agrupacion de Mujeres Meretrices de Argentina (AMMAR) elaborated further on their critiques of the terceria 
locativa. They signaled how many sex workers, especially those who are undocumented, share living spaces. With the pandemic, some of those living spaces have been used for sex work for reasons of survival during the economic crisis. The spokespeople stated their fear that suspecting neighbor could call the cops if they see people who, appear as sex workers, co-living. The groups reiterated how the criminalization measures would detriment their financial stability especially amidst a pandemic and a labor market that severely excludes undocumented and trans people (Aula Virtual Fundación de los Comunes, 2021). The spokespeople also articulated how the pandemic, and the greater financial distress it has caused sex workers, has curbed efforts to organize more directly in the streets.

Less visible but a powerful example of resistance to carceral feminism beyond sex work criminalization is an article published in El País by four feminist-activists and signed by more than 40 other anti-carceral activists, scholars and professionals. ${ }^{28}$ In the article, entitled "Feminist Objections to the Current Sexual Freedom Law", Laura Macaya, Cristina, Garaizabal, Empar Pineda and Clara Serra call for a feminism that "is committed to transformative policies outside of the abuse of penal code, which characterizes a conservative politics...that defends the rights of the most precarious and vulnerable women" (Garaizabal et.al., 2020). They express their skepticism of the capacity of affirmative consent to teach complicated cultural mores about sex and consent through the penal code. While they agree consent is basic for determining if a sexual act is violation, the authors argue The Yes Means Yes Law simplifies the realities of ordinary sex where there often is not an explicit yes. The seeks to change this pattern by plainly establishing a limit for women and naming any act that does not accompany a yes as a crime. This way of understanding consent as always an area of risk "promotes a sacralized and infantilized sexuality of women that prevents them from elaborating, for themselves and apart from state protection, strategies to establish limits against intrusive conducts" (Garaizabal et.al., 2020). As a result, The Yes Means Yes Law works less to further sexual freedom and more to re-establish tired patriarchal images of women as fragile and vulnerable.

\footnotetext{
${ }^{28}$ Many famous feminists and scholars referenced in this thesis signed the article including: Encarna BodelónGonzález, Paloma Uría-Ríos, Maria Luisa Maqueda-Abreu and Dolores Juliano.
} 
There are other glimpses of anti-carceral resistances to The Yes Means Yes Law across more subversive feminist magazines authored by feminist activists and scholars. One example is Pikara Magazine which features a plethora of critiques of the rise of punitive populism in the Spanish feminist movement and specifically within The Yes Means Yes Law. This archipelago of resistance, though, appears much more disjointed and indicates an important silence that, as Foucault (1980) reminds us, signals an action of silencing from hegemonic discourses. That is, institutional feminism still maintains a firm grip on the feminist movement's alliance with justice systems.

\section{Reflections: mapping convergences and divergences}

By examining the categories "victim" and "justice", my goal was to elicit the converging and diverging interpretations of victimhood, accountability and healing in each law. In other words, I sought to compare the overarching and specific carceral discourses explicitly and implicitly present in the respective legislation and the similar and distinct resistances that accompanied them. My analyses evince how victimhood and justice is bent on a globalizing and encroaching neoliberal project that supports normative identities, punishment and paternal protection. In this discussion, I combine my analysis of Law 1/2004 and The Yes Means Yes Law to map their points of agreement and conflict. Comparing carceral logics in each law provides an opportunity to show the trajectory of punitive demands (and resistance therein) since their early emergence in 2004 until their more mature development in The Yes Means Yes Law. I organize my reflections in several key themes: hidden punitive demands, the ideal victim, punitive and paternal justice and dispersed resistance.

\section{Hidden punitive demands}

In my analyses, I was surprised by how the carceral demands hid behind the shiny exterior of rehabilitative interventions. Each law introduces gender violence as a structural problem that necessitates a structural response and pride themselves on the action taken to include holistic solutions in the areas of health, education, social welfare and labor. The laws associate these measures with the efforts of feminist collectives who have long struggled for comprehensive 
legislative. However, my analyses reveal how the restorative aspects of the law are overshadowed and dulled by its punitive parts. Not only are non-penal interventions underfunded but they are also not always fully "pure" and sometimes contain carceral tactics within them.

\section{Ideal victims}

Second, I find elements of ideal victim narratives common in neoliberal crime control discourses. This is evident in how both laws center a cis-heterosexual woman victim and lack meaningful measures to addresses difference. One key example of how the law caters to white victimhood is how they require people to register with the criminal justice system to attain victim-status and access "right to no violence" assistance mechanisms. The laws also diverge in several key aspects: The Yes Means Yes Law places a greater (face-value) focus on intersectionality and takes a wider approach to what is considered an act of sexual violence. Even if the laws did not incorporate intersectional interventions (or worse, hide punitive measures behind restorative language), the inclusion of the concept of intersectionality represents a push-back from marginalized collectives against normative victimhood. Finally, The Yes Means Yes Law amplifies sexual violence beyond the narrow conjugal affective framework presented in Law $1 / 2004$, which was harshly criticized by feminist collectives.

\section{Punitive and paternal justice}

Thirdly, both laws propose punitive and paternal visions of justice. In both cases, the laws associate the rectification of harm with a speedy and harsh conviction. They also view the codification of new crimes and penalties as a feminist achievement that will help foster gender equality. I argue how this philosophy ends up individualizing instances of gender violence rather than treating it as the structural problem they describe it as in their motivation statements. In addition, both laws pretend to know what is best for victims and strip them of agency to make decisions for themselves. I argue how this reinforces traditional stereotypes of feminine vulnerability that acts more as a force of social control rather than liberation. Prominent examples of this are how Law 1/2004 permits court proceedings without the victim's consent and how The 
Yes Means Yes Law do not give sex workers the capacity to consent by deeming all their labor as sexual violence. On the contrary, because of its sexual violence rather than intimate partner scope, The Yes Means Yes Law infringes more on sex work and, thus, criminalizes behaviors beyond gender violence. European Union protocols, like the Istanbul Convention and Palermo Protocol, also informed more of The Yes Means Yes Law's frameworks, making globalizing punitive discourses and tactics (affirmative consent) even more apparent.

\section{Dispersed resistances}

Lastly, the resistances to Law 1/2004 and The Yes Means Yes Law show common characteristics. Namely, institutional feminism has invisibilized much of anti-carceral discourses using rhetoric that paint opponents as gender violence apologists. Both sections feature dispersed resistances from decentralized collectives of migrants, social workers and activists, academics and other professionals. As such, both resistances lack a more systematic movement against carceral feminism, but they still represent important points of disapproval. The main difference between the respective resistance was the large collectives of sex workers who have spoken out against The Yes Means Yes Law. Sex workers, operating in different organizations, wrote collective manifestos and letters and organized online conferences. Their efforts make the criminalization of sex work more apparent than those of other groups who have criticized gender violence-specific carceral tactics. By gender-violence specific tactics, I refer to the belief that higher sentences, speedier convictions, more police involvement and suppression of victim consent will eradicate gender violence.

This discussion provides clarity of how punitive tactics settle into different historical time periods and political contexts in Spain. The analysis connects the major thematic carceral discourses in both pieces of legislation while highlighting how certain punitive strategies and resistances follow a different course. With the final research question addressed, I shift to the final remarks where I sum up the purpose and goals of the project, the findings and reflections, and my past and future desires. 


\section{(NOT SO) FINAL THOUGHTS}

This thesis traces the global punitive discourses in two major pieces of Spanish gender violence legislation: Law 1/2004 and The Yes Means Yes Law. My goal of the research is to locate elements of carceral discourses that correspond to larger trends in globalizing neoliberal governance. My analyses specifically serve to draw the convergences and divergences between the punitive logics and strategies in Law 1/2004 and The Yes Means Yes Law as well as the resistances that the laws triggered. I analyze the Laws using a blended methodology between critical discourse analysis and genealogy (Anais, 2013). Because critical discourse analysis is a wide field, I draw on overarching analytical elements from Fairclough (1989; 1995) and more specific criticism from feminists (Lazar, 2007; 2018) and legal scholars (Rajah, 2018).

I reach several key reflections and findings in response to the initial research questions formulated in the introduction. I observe how many early post-Franco feminists were highly skeptical of the criminal justice system to resolve gender violence, yet the rise of institutional feminism in the 1980s pushed their concerns to the wayside and centered a punitive response that has remained until today. Upon analyzing the terms "victim" and "justice" in Law 1/2004 and The Yes Means Yes Law, I pinpoint the ideal victim and paternal justice as the main thematic carceral discourses. I identify migrants, social workers, sex workers and scholar/activists as the main collectives who disrupt carceral logics in each law but find how their lack of crossorganizational cohesion have dulled their resistance to institutional feminist punitive rhetoric. While examining the similarities between the two laws, I observe how they both contain nonpenal and penal demands and feature similar ideal victim narratives and punitive and paternal views of justice that increase sentences, codify new crimes and limit survivor consent. The laws diverge in their gender violence focus (Law 1/2004 legislates intimate partner violence and The Yes Means Yes Law sexual violence), treatment of difference and criminalization of sex work.

The theory and methodology chapters made the latter findings possible, yet they still warrant a critical reflection of whether they met all my intended goals and whether they serve as a potential resource for other activists and researchers. I found that entangling activism and theory is essential to working with anti-carceral feminisms given that "carceral feminism" is not an 
objective, self-evident fact but rather an observed and constructed phenomena that would not have been named without the political and intellectual work done by both activists and scholars. For that reason, I recommend other researchers working with anti-carceral feminisms to not let theory escape the practical roots of activism. On a similar note, I particularly encourage researchers who explore cross-Atlantic and global dimensions of anti-carceral feminism to pay close attention to the politics of location. Traveling concepts served as a highly illuminative tool to question the limits of US anti-carceral feminisms as a basis for resistance in other geographical spaces and to encourage the use of local ideas and actions. In relation to methodology, blending genealogy and critical discourse analysis effectively appealed to feminist principles of relationality and contestation while maintaining a practical and approachable analysis. Nonetheless, I believe I could have further engaged in self-reflexivity by interviewing on-the-ground activists and professionals. In previous research, I have been excited by how situated interactions between interviewees and interviewers and the conflux of presented identities, behaviors and language can spark unique knowledge related to research questions.

These findings, nor the theories that sustain them, are meant to be tidy nor perfect, new nor complete. This project is an amalgam of ongoing critique and conversations designed to push the needle forward for an anti-carceral feminist politics in a manner that is loyal to my feminist desire to transform how we think about victimhood and justice. Transformative justice theories and practices, despite their limitations, fill a necessary gap in reimagining long-term, distributional policies amongst an ever-present storm of neoliberal individualization, punitivism and paternalism. Through my travels to Spain, I encountered many scholars and activists who have dreams like I do. Their critiques of neoliberal feminism's alliance with patriarchal justice systems resonated with my own doubts about mainstream US feminist demands. By weaving together anti-carceral knowledges and practices, I explored the possibilities for an even bigger dream- a global anti-carceral feminist resistance. 


\section{REFERENCES}

Álvarez, P. (2021, May 21). Femicidios: Cinco asesinatos machistas en cuatro días, un efecto del fin de las restricciones. El País. https://elpais.com/sociedad/2021-05-21/cincoasesinatos-machistas-en-cuatro-dias-un-efecto-del-fin-de-las-restricciones.html

Álvarez, P. (2018, May 3). 'Running of the bulls' gang rape verdict sparks international debate. El País.

https://english.elpais.com/elpais/2018/05/03/inenglish/1525332569 996610.html?rel=m $\underline{\text { as }}$

Amnesty International. (2020a, December 17). Let's talk about 'yes': Consent laws in Europe. https://www.amnesty.org/en/latest/campaigns/2020/12/consent-based-rape-laws-ineurope/

Amnesty International. (2020b). Europe: Policing the pandemic: Human rights violations in the enforcement of COVID-19 measures in Europe. https://www.amnesty.org/download/Documents/EUR0125112020ENGLISH.PDF

Anais, S. (2013). Genealogy and critical discourse analysis in conversations: Texts, discourse, critique. Routledge: Critical Discourse Studies 10(2), 123-135.

Arroyo, J. (2021, June 11). Juana Rivas ingresa en un centro de inserción social en Granada para cumplir condena por la sustracción de sus hijos. El País. https://elpais.com/sociedad/2021-06-11/juana-rivas-ingresa-en-una-prision-de-granadapara-cumplir-condena-por-la-sustraccion-de-sus-hijos.html

Asociación de Investigación y Especialización Sobre Temas Iberoamericanos. (2020). Mujeres migrantes víctimas de violencia de género en España: Segundo informe. https://aieti.es/wp-content/uploads/2020/12/Documento 2DO-.pdf

Aula Virtual Fundación de los Comunes. (2021, February 23). Feminismo Punitivista en la ley sí es sí? [Video]. YouTube. https://www.youtube.com/watch?v=pO4k5snp-NU\&t=227s

Ávila-Cantos, D., \& García-García, S. (2013). Between risk and emergency: the increasing police approach in social interventions strategies. Revista de Antropología Social, 22, 59-82.

Ayuso, A. (2021, October 6). Síndrome de alienación parental: el trastorno pseudocientífico que le arrebató la hija a Irune Costumero. El Independiente. 
https://www.elindependiente.com/sociedad/2021/06/10/sindrome-de-alienacionparental-el-trastorno-pseudocientifico-que-le-arrebato-la-hija-a-irune-costumero/

Bergoffen, D. B. (2012). Contesting the politics of genocidal rape: affirming the dignity of the vulnerable body. New York: Routledge

Bey, M. (2021). Trouble Genders: "LGBT collapse” and trans fundamentality. Hypatia, 36, 191206.

Blueprint of the Organic Law, on the comprehensive guarantee of sexual freedom. Draft, 28 of October 2020. Spain. file:///C:/Users/arosa/Downloads/Yes\%20Means\%20Yes\%20Law.pdf

Bodelón-González, E. (2020). Confinadas: El control social de las mujeres durante la pandemia del Covid. Una visión feminista sobre el doble confinamiento de las mujeres. In I. Rivera-Beiras (Ed), Pandemia, Derechos Humanos, Sistema Penal y Control Social (en tiempos de coronavirus). Editorial Tirant Lo Branch.

Bumiller, K. (2008). In an abusive state. How neoliberalism apropiated the feminist movement against sexual violence. Durham, NC: Duke University Press.

Clifton, D. (2020, November 11). At least 350 transgender people have been killed globally in 2020. Them. https://www.them.us/story/at-least-350-transgender-people-killed-globallyin-2020

Cadena Ser. (2021, November 6). España sale a la calle para conjurarse contra la violencia machista. https://cadenaser.com/ser/2021/06/11/sociedad/1623398541_505383.html

Coker, D. (2001). Crime control and feminist law reform in domestic violence law: A critical review. Buffalo Criminal Law Review, 4, 801-860.

Consejo General del Poder Judicial. (2020, June 17). Informe sobre los 1000 primeros casos de víctimas mortales por violencia de género en el ámbito de la pareja o ex pareja. file:///C:/Users/arosa/Downloads/20200618\%201000\%20muertes\%20por\%20violencia \%20de\%20g\%C3\%A9nero.pdf

Consejo General del Trabajo Social. (2018, August 28). Posicionamiento del CGTS ante el RD Ley 9/2018 de medidas urgentes para el desarrollo del Pacto de Estado contra la violencia de género.

Council of Europe. (2005). Convention on action against trafficking in human beings (Palermo Protocol) (No. 197). https://rm.coe.int/168008371d 
Council of Europe. (2011). Convention on preventing and combating violence against women and domestic violence (Istanbul Convention) (No. 210).

https://www.coe.int/en/web/conventions/full-list/-/conventions/treaty/210?module=treatydetail\&treatynum $=210$

Council of Europe. (2021, November 8). Chart of signatures and ratifications of Treaty 210. https://www.coe.int/en/web/conventions/full-list/-/conventions/treaty/210?module=treatydetail\&treatynum=210https://www.coe.int/en/web/conventions/full-list//conventions/treaty $/ 210$ ?module=signatures-by-treaty\&treatynum $=210$

Crenshaw, K. (1989). Demarginalizing the intersection of race and sex: A black feminist critique of anti-discrimination doctrine, feminist theory and antiracist politics. University of Chicago Legal Forum, 1989(1), pp. 139-167.

El País. (2002, September 10). El PP rechaza en solitario en el Congreso el plan del PSOE contra los malos tratos. https://elpais.com/sociedad/2002/09/10/actualidad/1031608801 850215.html

El País. (2016, May 17). The legacy of the 15-M movement. https://english.elpais.com/elpais/2016/05/17/inenglish/1463480615_234660.html EuropaPress. (2021a, June 13). Irene Montero se compromete a llevar la ley del 'solo sí es sí' al Congreso antes del verano. https://www.europapress.es/sociedad/noticia-irenemontero-compromete-llevar-ley-solo-si-si-congreso-antes-verano20210613155628.html

EuropaPress. (2021b, July 6). Irene Montero sobre la ley del 'solo si es sí': 'Te libera de tener que demostrar que te has resistido. https://www.europapress.es/epsocial/igualdad/noticia-irene-montero-ley-solo-si-si-telibera-tener-demostrar-te-has-resistido-20210706143758.html

European Parliament (2014). Resolution on sexual exploitation and prostitution and its impact on gender equality (2013/2013(INI)). Strasbourg. (https://www.europarl.europa.eu/doceo/document/TA-7-2014-0162 EN.html?redirect

Expansión. (n.d.). Presupuestos generales del estado- España. https://datosmacro.expansion.com/estado/presupuestos/espana?sc=PR-G-F-11

Farris, S. (2017). In the name of women's rights: The rise of femonationalism. Duke University Press. 
Fairclough, N. (1989). Language and power. London: Longman.

Fairclough, N. (1995). Critical discourse analysis: The critical study of language. London: Longman.

Foucault, M. (1975). Discipline and punish: The birth of the prison. Gallimard.

Foucault, M. (1980). Power and Knowledge: Selected Interviews and Other Writings 19721977. New York: Pantheon Books.

Garaizabal C., L. Macaya, E. Pineda, C. Serra. (2021, March 1). Objeciones feministas al actual proyecto de ley de libertades sexuales. El País. https://elpais.com/opinion/202102-28/objeciones-feministas-al-actual-proyecto-de-ley-de-libertadessexuales.html?event log=oklogin

Gil, S. (2011). Nuevos feminismos: Sintiendo comunes en la dispersión. Traficantes de Sueños.

Goodmark, L. (2021). Reimagining VAWA: Why criminalization is a failed policy and what a non-carceral VAWA could look like. Violence Against Women, 27(1), 84-101.

Gottschalk, M. (2006). The prison and the gallows: The politics of mass incarceration in America. Cambridge University Press.

Gruber, A. (2020). The Feminist War on Crime: The unexpected role of women's liberation in mass incarceration. University of California Press. Kindle Version.

Guede. A \& López-Macías, J. (2021, February 25). Los jueces rechazan por unanimidad los puntos clave de la ley 'si es si' de Irene Montero. 20 Minutos.

https://wgondww.20minutos.es/noticia/4598911/0/poder-judicial-critica-unisono-ley-sies-si-montero/

Halley, J. (2008). Split decisions: How and why to take a break from feminism. Princeton, NJ: Princeton University Press.

Halley, J. (2016). The move to affirmative consent. Signs: Journal of Women in Culture and Society, 42(1), 257-278.

Harvey, D. (2007). A Brief History of Neoliberalism. Oxford University Press.

Hedgecoe, G. (2019, November 19). Spanish elections: How the far-right Vox party found its footing. BBC News. https://www.bbc.com/news/world-europe-46422036

hooks, b. (1991). Theory as liberatory practice. Yale Journal of Law and Feminism, 4(1), 1-12. 
Juliano, D. (2020). Feminismo y el derecho penal, una relación penosa. In D. Daich \& C. Varela, (Eds.), Los feminismos en la encrucijada del punitivismo. (pp. 27-38). Editorial Biblios.

Kelley M. L., Lewis R. J., Milletich R. J., Woody A. (2012). Minority stress, substance use, and intimate partner violence among sexual minority women. Aggress. Violent Behav. 17 115-119. 10.1016/j.avb.2012.02.004

Kim, M. E. (2020a). Transformative justice and restorative justice: Gender-based violence and alternative visions of justice in the United States. International Review of Victimology, (20201126). https://doi.org/10.1177/0269758020970414

Kim, M. E. (2020b). Anti-carceral feminism: the contradictions of progress and the possibilities of counter-hegemonic struggle. Affilia, 35(3), 309-326. https://doi.org/10.1177/0886109919878276

Kushner, R. (2019, April). Is prison necessary? Ruth Wilson Gilmore might change your mind. New York Times.

La Moncloa. (2021, March 18). Igualdad inicia sus trabajos para la elaboración de una ley contra la trata. Gobierno de Espana.

Larrauri, E. (2007). Criminología crítica y violencia de género. Editorial Trotta.

Laurenzo-Copello, P., Maqueda Abreu, M.L, \& Rubio-Castro, A.M. (2008). Género, violencia y derecho. Tirant lo Blanch.

Lazar, M.M. (2007). Politicizing gender in discourse: Feminist critical discourse analysis as political perspective and practice. In M.M. Lazar (Ed.), Feminist Critical Discourse Analysis: Gender, Power and ldeology in Discourse. (pp. 1-28). Palgrave MacMillan.

Lazar, M.M. (2018). Feminist critical discourse studies. In J. Flowerdew \& J.E. Richardson (Eds.), The Routledge Handbook of Critical Discourse Studies. Routledge.

Libertad Digital. (2002, September 18). Aznar califica de 'leyes genericas' la propuesta del PSOE contra la violencia de género. https://www.libertaddigital.com/sociedad/2002-0918/aznar-califica-de-leyes-genericas-la-propuesta-del-psoe-contra-la-violencia-degenero-1275317945/

Martín, J. (2020, March 3). La ley del 'solo si es si': penas hasta 15 años de cárcel para el delito de violación y el consentimiento como clave. rtve. 
https://www.rtve.es/noticias/20200303/ley-del-solo-si-si-penas-1-4-anos-agresion-sinconsentimiento/2005130.shtml

Martín, M. (2020, February 20). Spain 's coalition government clashes over immigration crackdown. El País. https://english.elpais.com/politics/2020-02-20/spains-coalitiongovernment-clashes-over-immigration-crackdown.html

Martinez, M. (2017). From the subjected subject to the vulnerable subject: An unfinished discussion in contemporary Spanish feminisms. Signs: 43(2), pp. 327-351.

Martínez-Riber, R. (2020, September 25). La abolición de la prostitucion: una necesidad incuestionable. PSOE. https://www.psoe.es/el-socialista/opina-en-el-socialista/laabolicion-de-la-prostitucion-una-necesidad-incuestionable/

McCloskey, K. \& Sitaker, M. (2009). Backs against the wall: battered women's resistance strategies. Routledge.

Mendez, L. (2021, June 6). España: aumentan los femicidios tras el fin de las restricciones por la pandemia. rfi. https://www.rfi.fr/es/europa/20210618-espa\%C3\%B1a-aumentan-losfeminicidios-tras-fin-de-las-restricciones-por-la-pandemia

Messinger, A. M. (2011). Invisible victims: same-sex IPV in the national violence against women survey. J. Interpers. Violence 26 2228-2243. 10.1177/0886260510383023

Minder, R. (2020, January 15). Overlooked no more: Ana Orantes, whose gruesome murder brought change to Spain. New York Times.

Ministerio de Igualdad. (2017). State pact against gender violence. Delegación del Gobierno para la violencia de género.

https://violenciagenero.igualdad.gob.es/pactoEstado/docs/FolletoPEVGcastweb.pdf

Ministerio de Igualdad. (2020). Ampliación del Plan de Contingencia contra la violencia de género ante la crisis del COVID-19: medidas adicionales dirigidas a víctimas de trata, explotación sexual y a mujeres en contextos de prostitución. https://observatorioviolencia.org/wp-content/uploads/Plan-Vi\%C4\%9Bctimastrata COVID definitivo.pdf

Missing Migrants Project. (2021, August 8). Total deaths recorded in the Mediterranean from 01 January to 09 August. https://missingmigrants.iom.int/region/mediterranean 
Moreno, S. (2021, June 11). El ex novio de Rocio Caiz, la menor de 17 años desaparecida en Sevilla, confiesa que le descuartizó y tiró sus restos. El Mundo. https://www.elmundo.es/andalucia/sevilla/2021/06/10/60c273a7fc6c8314088b4653.html

Moten, F \& Harney, S. (2013). The undercommons: Fugitive planning and black study. Minor Compositions.

National Coalition Against Domestic Violence. Why do victims stay? NCDAV. https://ncadv.org/why-do-victims-stay

Neumann, B. \& Nünning, A. (2012). Travelling concepts for the study of culture. Berlin, Boston: De Gruyter. https://doi.org/10.1515/9783110227628

Nogueira, C. (2004, October 8). El Congreso aprueba por unanimidad la ley integral contra la violencia de género. El País. https://elpais.com/diario/2004/10/08/sociedad/1097186401 850215.html

Novisky, M. A., \& Peralta, R. L. (2015). When women tell: intimate partner violence and the factors related to police notification. Violence against women, 21(1), 65-86. https://doi.org/10.1177/1077801214564078

Núñez-Puente, S. \& Fernández-Romero, D. (2015). Construcción identitaria del sujeto víctima de violencia de género: fetichismo, estetización e identidad públicas. Revista Teknokultura, Vol. 12(2), 267-284.

Organic Law 10/1995, on the Penal Code. BOE, n 281, of November 23, 1995, Spain.

Organic Law 1/2004, on measures for comprehensive protection from gender violence. BOE, $n$ 313, of December 28, 2004, Spain.

https://www.cgtrabajosocial.es/comunicaciones/comunicado-posicionamiento-del-cgts-ante-elrd-ley-9-2018-de-medidas-urgentes-para-el-desarrollo-del-pacto-de-estado-contra-laviolencia-de-genero/396/view

Pineda. A. (2006, March 18). Un feminismo que también existe. El País. https://elpais.com/diario/2006/03/18/opinion/1142636413 850215.html

Rainsford, S.. (2011, October 15). Spain's 'Indignants' lead international protest day. BBC. https://www.bbc.com/news/world-europe-15315270

Rajah, J. (2018). Legal discourse. In J. Flowerdew \& J.E. Richardson (Eds.), The Routledge Handbook of Critical Discourse Studies. Routledge. 
Richie, B.E. (2000). A black feminist reflection on the antiviolence movement." Signs 25(4):1133-37.

Rights International Spain. (2020, December 1). Policy webinar on ethnic profiling. http://www.rightsinternationalspain.org/en/blog/169/policy-webinar-on-ethnic-profiling

Saiz, E. (2020, June 4). Four members of 'the wolfpack' given fresh prison terms for abusing an unconscious woman. El País. https://english.elpais.com/spanish news/2020-0604/spains-la-manada-convicted-in-new-sex-abuse-case.html

Santana, A. (2021, February 26). El silencio no es un sí: así es la ley de libertad sexual que plantea España. France 24. https://www.france24.com/es/europa/20210225-leyconsentimiento-libertad-sexual-espana

Sherman, L. W., Schmidt, J. D., Rogan, D. P., Gartin, P. R., Cohn, E. G, Collins, D. J., \& Bacich, A. R. (1992). The variable effects of arrest on criminal careers: The Milwaukee Domestic Violence Experiment. Journal of Criminal Law and Criminology, 83(1), 137169.

Spade, D. (2013). Intersectional resistance and law reform. Signs 38(4), 1031-055. University of Chicago Press.

Stanley, E., and Smith, N. (Eds.). (2011). Captive Genders: Trans embodiment and the prison industrial complex. AK Press.

Thuma, E. (2019). All our trials: Prisons, policing and the feminist fight to end violence. University of Illinois Press.

20 Minutos. (2021, June 21). La presidenta del Consejo de Igualdad del PSOE critica la ley trans: 'Estamos en contra; Carmen Calvo no está sola.' https://www.20minutos.es/noticia/4742624/0/la-presidenta-del-consejo-de-igualdad-delpsoe-critica-la-ley-trans-estamos-en-contra-carmen-calvo-no-esta-sola/

Turrell, S. C. (2000). A descriptive analysis of same-sex relationship violence for a diverse sample. Journal of Family Violence, 15(3), 281-293. https://doi.org/10.1023/A:1007505619577

United Nations. (1995). Report of the fourth world conference on women. Beijing. https://undocs.org/en/A/CONF.177/20/Rev.1 
United Nations. (2010). Handbook for legislation on violence against women.

https://www.un.org/womenwatch/daw/vaw/handbook/Handbook\%20for\%20legislation\% 20on\%20violence\%20against\%20women.pdf

United Nations General Assembly. (1979). Convention on elimination of all forms of discrimination against women (34-180). New York. https://www.ohchr.org/Documents/Professionallnterest/cedaw.pdf

United Nations General Assembly. (1993). Declaration on the elimination of violence against women (48/104).

https://www.ohchr.org/en/professionalinterest/pages/violenceagainstwomen.aspx

Uría-Ríos, P. (2009). El feminismo que no llegó al poder. Talasa Ediciones.

Valenzuela-Vela, L. \& Alcázar-Campos, A. (2019). Gendered carceral logics in social work: the blurred boundaries in gender equality policies for imprisoned and battered women in Spain. Affilia: Journal of Women and Social Work, 20(10), 1-16.

Varona-Gómez, D. \& Gabarrón, N. (2015). El tratamiento mediático de la violencia de género en España (2000-2012): agenda setting y agenda building. InDret (2),, 2015(2). https://raco.cat/index.php//nDret/article/view/293105.

Vega, G. (2021, June 13). Carta de la madre de las niñas: 'Deseo la muerte de Anna y Olivia no haya sido en vano.' El País. https://elpais.com/sociedad/2021-06-13/carta-de-lamadre-de-las-ninas-deseo-que-la-muerte-de-anna-y-olivia-no-haya-sido-en-vano.html

Working of Experts on People of African Descent. (2020). COVID-19, systemic racism and global protests. United Nations Human Rights Council. https://undocs.org/en/A/HRC/45/44

Waters, E., Hurhangee, R., Misclevitz, C., MacDade, L., Essex, L., Presley, C., Romero, K., Dechane, C., Musquiz, R., Wood, C., Campbell, C., Sprague, L., Pica, A., Tran, H., Shugrue dos Santos, C., Yacka, S., Pham, L., Chestnut, S., Sullivan, J.,...Holt, S. (2015). Lesbian, gay, bisexual, transgender, queer and HIV-affected intimate partner violence in 2015 (2016 release edition). National Coalition of Anti-Violence Programs. http://avp.org/wp-content/uploads/2017/04/2015 ncavp Igbtqipvreport.pdf

Wacquant, L. (2009). Punishing the poor: The neoliberal government of social insecurity. Duke University Press. 
World Population Review. (2021). Incarceration rates by country 2021. https://worldpopulationreview.com/country-rankings/incarceration-rates-by-country

Xie, M., \& Lynch, J. P. (2017). The effects of arrest, reporting to the police, and victim services on intimate partner violence. Journal of Research in Crime and Delinquency, 54(3), 338-378. https://doi.org/10.1177/0022427816678035 